\title{
Impact of precipitation and land biophysical variables on the simulated discharge of European and Mediterranean rivers
}

\author{
C. Szczypta, B. Decharme, D. Carrer, J.-C. Calvet, S. Lafont, S. Somot, S. Faroux, and E. Martin \\ Groupe d'étude de l'atmosphère météorologique (GAME), URA1357, CNRS - Météo-France, Toulouse, France
}

Correspondence to: J.-C. Calvet (jean-christophe.calvet@meteo.fr)

Received: 21 March 2012 - Published in Hydrol. Earth Syst. Sci. Discuss.: 24 April 2012

Revised: 23 July 2012 - Accepted: 22 August 2012 - Published: 20 September 2012

\begin{abstract}
This study investigates the impact on river discharge simulations of errors in the precipitation forcing, together with changes in the representation of vegetation variables and of plant transpiration. The most recent European Centre for Medium-Range Weather Forecasts reanalysis (ERA-Interim) is used to drive the Interactions between Soil, Biosphere, and Atmosphere-Total Runoff Integrating Pathways (ISBA-TRIP) continental hydrological system over Europe and the Mediterranean basin over the 1991-2008 period. As ERA-Interim tends to underestimate precipitation, a number of precipitation corrections are proposed. In particular, the monthly Global Precipitation Climatology Centre (GPCC) precipitation product is used to biascorrect the 3-hourly ERA-Interim estimates. This correction markedly improves the match between the ISBA-TRIP simulations and the river discharge observations from the Global Runoff Data Centre (GRDC), at 150 gauging stations. The impact on TRIP river discharge simulations of various representations of the evapotranspiration in the ISBA land surface model is investigated as well: ISBA is used together with its upgraded carbon flux version (ISBA-A-gs). The latter is either driven by the satellite-derived climatology of the Leaf Area Index (LAI) used by ISBA, or performs prognostic LAI simulations. The ISBA-A-gs model, with or without dynamically simulated LAI, allows a better representation of river discharge at low water levels. On the other hand, ISBA-Ags does not perform as well as the original ISBA model at springtime.
\end{abstract}

\section{Introduction}

Over the last decades, Europe was affected by severe drought events. The drought of 2003 had a marked impact on agriculture and industry over Western and Central Europe (Ciais et al., 2005; Vidal et al., 2010). In 2004 and in 2010, respectively, severe droughts affected the Iberian Peninsula (García-Herrera et al., 2007) and Russia (Barriopedro et al., 2011). Drought duration and location are variable but always have economic, social and environmental impacts. As a result, it is necessary to understand these events and to predict when and where they will occur. Even if no universally accepted definition of drought exists (Tate and Gustard, 2000), three consistent drought categories are frequently used and have been defined by Wilhite and Glantz (1985): meteorological drought (deficit in precipitation), agricultural drought (deficit in soil moisture, and/or in Leaf Area Index - LAI) and hydrological drought (e.g. deficit in river discharge). Modelling platforms including land surface models (LSMs), forced by gridded atmospheric variables and coupled to river routing models, represent efficient and powerful tools to understand the global hydrological cycle and to study different drought types (Dirmeyer et al., 2006). While precipitation data allow the evaluation of meteorological droughts, LSMs coupled to runoff models are needed to characterize agricultural and hydrological droughts, with simulated biophysical variables (LAI, surface and root-zone soil moisture) fully consistent with surface flux (latent and sensible heat fluxes, $\mathrm{CO}_{2}$ fluxes) and river discharge simulations. Indeed, the LSM performance impacts the hydrological simulations (Lohmann et al., 1998; Boone et al., 2004; Decharme, 2007; Balsamo et al., 2009). LSMs were significantly improved over recent decades and can now be coupled with 
river routing schemes to understand the regional and global water cycles (Dümenil and Todini, 1992; Habets et al., 1999; Oki et al., 1999; Decharme et al., 2006).

The Mediterranean basin will probably be affected by climate change to a large extent (Gibelin and Déqué, 2003; Giorgi, 2006; Planton et al., 2012). The fourth assessment report of the Intergovernmental Panel on Climate Change (IPCC) emphasized that over Europe and Mediterranean areas, the annual mean temperature of the air is likely to increase more than the global mean. In most Mediterranean regions, this trend would be associated with a decrease in annual precipitation (Christensen et al., 2007). In this context, it is important to build monitoring systems of the land surface variables and of the hydrological variables over this region, able to describe extreme climatic events such as droughts and to analyze their severity with respect to past droughts. In the framework of the HYMEX (HYdrological cycle in the Mediterranean EXperiment) project (HYMEX White Book, 2008) and particularly with the aim of simulating hydrological droughts over the 1991-2008 period, river discharge simulations were performed with the ISBA (Interactions between Soil, Biosphere, and Atmosphere) LSM (Noilhan and Planton, 1989; Noilhan and Mahfouf, 1996) coupled with the Total Runoff Integrating Pathways (TRIP; Oki et al., 1997) model over Europe and the Mediterranean basin. The ISBA LSM was developed at Météo-France to describe the land surface processes in weather forecast and climate models. ISBA uses a limited number of parameters, mapped according to the soil and vegetation types provided by the global $1 \mathrm{~km} \times 1 \mathrm{~km}$ resolution ECOCLIMAP land cover and lookup table database (Masson et al., 2003). The European Center for Medium range Weather Forecasts (ECMWF) ERAInterim (ERA-I) gridded atmospheric reanalysis (Simmons et al., 2007; Dee et al., 2011) was used to drive the coupled ISBA-TRIP continental hydrological system.

The river discharge simulated by the ISBA-TRIP system results from the following water fluxes: (1) the ERA-I precipitation, and (2) the simulated soil moisture changes, evapotranspiration, surface runoff and drainage. Therefore, provided bias-corrected precipitation data are used (Fekete et al., 2003), and that errors caused by the coarse resolution spatial average of the atmospheric forcings combined with the non-linearity in the hydrological response are not too large (Van Dijk and Renzullo, 2011), the simulated river flow can be used for the intercomparison of LSM simulations (Boone et al., 2004). Szczypta et al. (2011) have shown that, over France, the ERA-I precipitation correlates very well with the SAFRAN (Système d'Analyse Fournissant des Renseignements A la Neige) analysis (Quintana-Segui et al., 2008) based on a dense network of in situ observations. However, ERA-I tends to markedly underestimate the precipitation, by $27 \%$ on average. Photiadou et al. (2011) have shown that the underestimated ERA-I precipitation leads to underestimated river discharges.
The two major objectives of this study are (1) to reduce the bias of the ERA-I precipitation using ancillary data and validate the bias-corrected precipitation through river discharge simulations, and (2) to test different LSM configurations driven by the best available atmospheric forcing. First, the ERA-I precipitation bias is characterized over Europe and the Mediterranean basin by comparing monthly ERA-I precipitation data with the monthly Global Precipitation Climatology Centre (GPCC) product (Rudolf et al., 2005), which is based on ground observations. The GPCC data are used to bias-correct the ERA-I 3-hourly precipitation. The original and the bias corrected ERA-I precipitation data sets are used by ISBA-TRIP to produce river discharge simulations. Following Decharme and Douville (2006b), the comparison between these simulations and the Global Runoff Data Centre (GRDC) daily observations are used to assess the added value of the bias-corrected ERA-I precipitation on the ISBATRIP simulations. Second, the relevance of using different precipitation fields and versions of ISBA LSM (the standard version or the $\mathrm{CO}_{2}$-responsive versions) is examined through ISBA-TRIP simulations of river discharge. ISBA-TRIP simulations based on the bias-corrected ERA-I precipitation are used to benchmark two versions of the ISBA model: the standard version and the ISBA-A-gs carbon version (Calvet et al., 1998; Gibelin et al., 2006). The latter uses either the same satellite-derived LAI climatology as the standard ISBA or produces prognostic LAI estimates. The impact of these LSM options and of LAI on the river discharge simulations is evaluated.

After an overview of the different data sets, models, scores and methods used in this study (Sect. 2), the results are presented in Sect. 3. The impact of precipitation on the runoff model simulations over Europe is presented, together with the impact of the carbon option of ISBA and LAI. These results are analyzed and discussed in Sect. 4, in relation to the water balance of the Mediterranean basin. The main conclusions of this study are summarized in Sect. 5.

\section{Data and methods}

Two independent sets of experiments were performed (Table 1): evaluation of the river discharges derived with (1) four different precipitation forcings, and (2) three different vegetation parameterizations.

\subsection{Meteorological variables}

The ERA-I atmospheric reanalysis is used in this study to drive the coupled ISBA-TRIP system over the 1991-2008 period, at a spatial resolution of $0.5^{\circ}$, corresponding to 8142 land grid cells over the considered area (see Fig. 1). 
Table 1. Description and references of the different configurations of the ISBA-TRIP river discharge simulations. It can be noted that ERAI-RG and NIT represent the same experiment.

\begin{tabular}{lccll}
\hline Simulation name & $\begin{array}{c}\text { GPCP-rescaled } \\
\text { precipitation }\end{array}$ & $\begin{array}{c}\text { GPCC-unbiased } \\
\text { precipitation }\end{array}$ & LSM & LAI \\
\hline ERA-I & & & ISBA-A-gs & ISBA-A-gs \\
ERA-I-R & $\checkmark$ & & ISBA-A-gs & ISBA-A-gs \\
ERA-I-G & & $\checkmark$ & ISBA-A-gs & ISBA-A-gs \\
ERA-I-RG & $\checkmark$ & $\checkmark$ & ISBA-A-gs & ISBA-A-gs \\
STD & $\checkmark$ & $\checkmark$ & Standard ISBA & ECOCLIMAP-II \\
AST & $\checkmark$ & $\checkmark$ & ISBA-A-gs & ECOCLIMAP-II \\
NIT & $\checkmark$ & $\checkmark$ & ISBA-A-gs & ISBA-A-gs \\
\hline
\end{tabular}

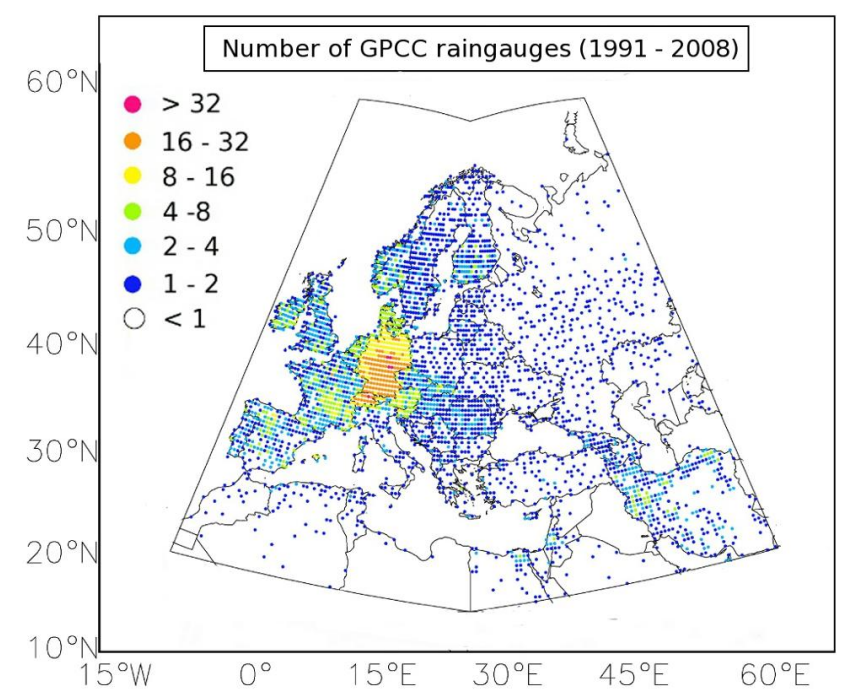

Fig. 1. Mean number of GPCC rain gauges per grid cell $\left(0.5^{\circ} \times 0.5^{\circ}\right)$ used to rescale the ERA-I precipitation data set over the 1991-2008 period.

\subsubsection{The ERA-I reanalysis}

The ECMWF ERA-I reanalysis covers dates from 1 January 1979 and is updated in near-real-time (with a delay of approximately one month). This data set is produced with an atmospheric model using a sequential data assimilation scheme based on 12-hourly analysis cycles. The available observations are used together with the previous forecast simulations to map the atmospheric fields (air temperature, wind speed, air humidity, atmospheric pressure). Furthermore, while producing a forecast, the atmospheric model simulates a large variety of physical variables such as precipitation, turbulent fluxes, radiation fields, and cloud properties. Even if these quantities are not directly observed, they are constrained by the observations used to initialize the forecast. All these forcing data were projected from the original reduced Gaussian grid (of about $0.7^{\circ} \times 0.7^{\circ}$ ) to a $0.5^{\circ} \times 0.5^{\circ}$ grid, at a 3-hourly time step. A full description of the data can be found in Simmons et al. (2007), and the assimilation system is described in Dee et al. (2011).

A verification of the different ERA-I atmospheric variables was performed over France by Szczypta et al. (2011). They found that, on average, the ERA-I precipitation is underestimated by $27 \%$ in comparison to the SAFRAN reference analysis based on thousands of rain gauges. A scaleselective rescaling procedure correcting for the ERA-I 3hourly precipitation bias was implemented by ECMWF (Balsamo et al., 2010), based on the monthly accumulated precipitation provided by the Global Precipitation Climatology Project (GPCP). The GPCP v2.1 product (Huffman et al., 2009) is a monthly global climatology generated on a $2.5^{\circ} \times 2.5^{\circ}$ grid and available over the 1979-2009 period. This data set is a merged product combining various observations related to precipitation, including satellite observations and rain gauge data, assembled and analyzed by the Global Precipitation Climatology Centre (GPCC, Rudolf et al., 2010) and by the Climate Prediction Center of the National Oceanic and Atmospheric Administration (NOAA). Note that GPCP v2.1 is an improved version of GPCP v2.0, described in Adler et al. (2003). Hereafter, the GPCP rescaled ERA-I precipitation will be referred to as ERA-I-R. The ERA-I-R precipitation correlates much better with the SAFRAN precipitation on a 3-hourly basis than ERA-I. Although the ERA-I-R rescaling is performed on a monthly basis using the GPCP precipitation, the correlation with SAFRAN is computed for a 18 -yr period, and for this reason, the correlation coefficient can be improved by the monthly bias correction (Sczcypta et al., 2011).

\subsubsection{Bias-corrected ERA-I precipitation based on the GPCC monthly product}

The GPCC provides a global monthly precipitation analysis at a $0.5^{\circ} \times 0.5^{\circ}$ resolution (GPCC v5) over the $1901-$ 2010 period (Becker, 2011). The GPCC monthly precipitation product is based on ground observations from more than 70000 rain gauge stations worldwide (Fuchs et al., 2009). Its quality depends on the density of rain gauges used to prepare the product. The GPCC network is relatively dense 
in Europe and in North America (Decharme and Douville, 2006b). Figure 1 presents the mean number of rain gauges per grid cell $\left(0.5^{\circ} \times 0.5^{\circ}\right)$ used to generate the GPCC precipitation data set in the area considered in this study over the 1991-2008 period. Over the considered area, 11263 rain gauges are used. While many rain gauges are used in Europe (especially in Germany), large parts of Russia, North Africa, Turkey, and the Middle East present a low density of in situ observations. Szczypta et al. (2011) showed that while ERA-I-R underestimates precipitation by $13 \%$ over France, GPCC underestimates precipitation by $5 \%$ only. In this study, the GPCC product is used to correct the systematic biases in the ERA-I and ERA-I-R 3-hourly reanalyses. The ERA-I and ERA-I-R 3-hourly spatial and temporal distributions of precipitation are preserved, while the biases with the monthly GPCC climatology are reduced. The hybridization of the two data sets with GPCC is performed as in Decharme and Douville (2006b):

$P_{\text {hybrid }}^{3 \mathrm{~h}}=P_{\mathrm{ERA}-\mathrm{I}}^{3 \mathrm{~h}} \times P_{\mathrm{GPCC}}^{\text {month }} / P_{\mathrm{ERA}-\mathrm{I}}^{\text {month }}$.

In arid/semi-arid regions and/or during the dry seasons, the ERA-I (or ERA-I-R) monthly precipitation can be equal to zero. In this case, no correction is done, and the corresponding ERA-I-G (or ERA-I-RG) 3-hourly precipitation remains equal to zero during the considered month, even if the corresponding GPCC monthly precipitation is not equal to zero.

Hereafter, the bias-corrected ERA-I and ERA-I-R precipitations based on the GPCC monthly product are referred to as ERA-I-G and ERA-I-RG, respectively (see Table 1).

\subsection{The GRDC river discharge data base}

The Global Runoff Data Center (GRDC, Koblenz, Germany, 2012) database is a collection of river discharge data at a daily or monthly time steps from more than 8000 stations worldwide. In this study, the GRDC daily data are selected over the domain presented in Fig. 1, for the 1991-2008 period, for sub-basins with drainage areas of at least $10000 \mathrm{~km}^{2}$ and with a minimum observed period of $5 \mathrm{yr}$. This results in 150 gauging stations, mainly located in Central, Eastern and Northen Europe and in France (hereafter referred to as "CNF"), as shown by Fig. 2 (red dots). Only one of these stations is located in North Africa (Algeria). For Southern Europe, the Middle East, and North Africa, i.e. for areas close to the Mediterranean Sea and to the Black Sea (hereafter referred to as "MBS"), GRDC data from 46 gauging stations are available over a past period (Fig. 2). The first time series starts in 1912 and for these stations, no data is available after 1994. Moreover, about half of the time series are available at a monthly time step only. Therefore, the MBS stations are used in this study to build a monthly climatology. Only subbasins with drainage areas of at least $5000 \mathrm{~km}^{2}$ and with a minimum observation period of $10 \mathrm{yr}$ are considered, except for the time series of the Po basin in Italy, which covers a 6-yr period (1980-1985) only.

\subsection{The SURFEX modelling platform}

The SURFEX (SURFace EXternalisée) modelling platform (Le Moigne, 2009) includes the ISBA and the ISBA-Ags LSMs, coupled with the TRIP river routing model. The LSMs simulate soil moisture and the associated surface runoff and deep drainage. The latter two variables are used by TRIP for the simulation of river flow.

\subsubsection{The ISBA LSM}

ISBA uses the force-restore method of Deardoff (1977, 1978) to calculate the time variation of the surface energy and water budgets (Noilhan and Planton, 1989). The soil hydrology is represented by three layers: a thin surface layer with a uniform depth, a root-zone layer, and a deep soil layer (Boone et al., 1999) contributing to evaporation through capillarity rises. Also, the model simulates the water interception storage and the snow pack evolution based on a simple onelayer scheme (Douville et al., 1995). The deep drainage is computed according to Noilhan and Mahfouf (1996).

ISBA also includes a comprehensive parameterization of sub-grid hydrology to account for the heterogeneity of precipitation, infiltration, topography and vegetation within each grid cell. A TOPMODEL approach (Beven and Kirkby, 1979) has been used to simulate a saturated fraction where precipitation is entirely converted into surface runoff (Decharme et al., 2006). Infiltration over frozen and unfrozen soils is computed via two sub-grid exponential distributions of rainfall intensity and soil maximum infiltration capacity. Finally, a tile approach, in which each grid cell is divided into a series of sub-grid patches, is used to represent land cover and soil depth heterogeneities. Distinct energy and water budgets are computed for each tile within a grid cell and the relative fractional coverage of each surface type is used to determine the grid-cell average of the various output variables. More details can be found in Decharme and Douville (2006a). The stomatal resistance of the vegetation is computed with a multiplicative model based on Jarvis (1976), where a minimum stomatal resistance is divided by stress functions representing the effect of solar radiation, soil moisture stress, air humidity and air temperature. The ISBA LSM uses a satellite-derived seasonal climatology of LAI provided by the ECOCLIMAP look-up tables.

\subsubsection{The ISBA-A-gs LSM}

On the basis of ISBA, Calvet et al. (1998) developed ISBA$\mathrm{A}-\mathrm{gs}$, which is a $\mathrm{CO}_{2}$-responsive version of ISBA. This model accounts for photosynthesis and its coupling with stomatal conductance at the leaf level. According to the model classification framework set out in Arora (2002), the photosynthesis model within ISBA-A-gs is based on a soilvegetation-atmosphere transfer biochemical approach. The representation of photosynthesis is based on the model of 

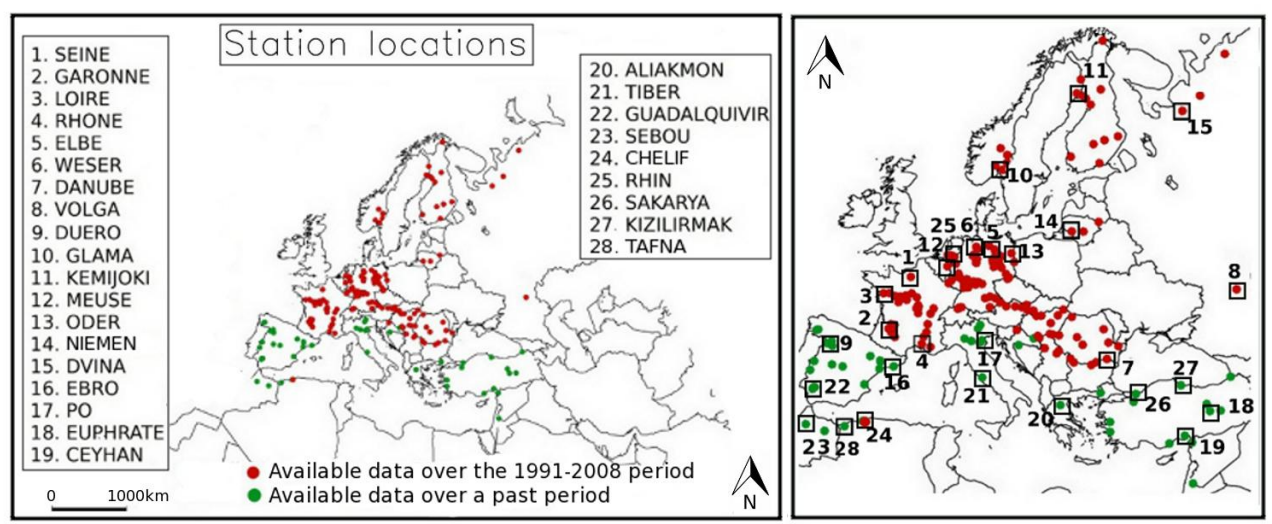

Fig. 2. (Left) overview of the available GRDC station locations over the considered area, for the 1991-2008 period in the CNF area and for a past period in the MBS area (red and green dots, respectively); and (right) the stations for which the river discharge is presented in Figs. 7 and 11 .

Goudriaan et al. (1985) modified by Jacobs (1994) and Jacobs et al. (1996). This parameterization is derived from the set of equations commonly used in other land surface models (Farquhar et al., 1980, for C3 plants, and Collatz et al., 1992, for C4 plants), and it has the same formulation for $\mathrm{C} 4$ plants as for $\mathrm{C} 3$ plants, differing only by the input parameters. Moreover, the slope of the response curve of the light-saturated net rate of $\mathrm{CO}_{2}$ assimilation to the internal $\mathrm{CO}_{2}$ concentration is represented by the mesophyll conductance, $g_{\mathrm{m}}$. Therefore, the value of the $g_{\mathrm{m}}$ parameter is related to the activity of the Rubisco enzyme (Jacobs et al., 1996), while in the Farquhar model this quantity is represented by a maximum carboxylation rate parameter, $V_{\mathrm{C} \text {,max }}$. The model also includes an original representation of the soil moisture stress. Two different types of the plant response to drought are distinguished, for both herbaceous vegetation (Calvet, 2000) and forests (Calvet et al., 2004). The plant response to drought is characterized by the evolution of the water use efficiency (WUE) under moderate stress: WUE increases in the early soil water stress stages in the case of the drought-avoiding response, whereas WUE decreases or remains stable in the case of the drought-tolerant response. This is achieved through the parameterization of the impact of soil-moisture on $g_{\mathrm{m}}$ and on other parameters of the photosynthesis model. The approach for carbon allocation and for phenology is specific to the ISBA-A-gs model and is based on a simple growth model driven by photosynthesis (Calvet et al., 1998; Calvet and Soussana, 2001). The leaf biomass is supplied with the carbon assimilated by photosynthesis, and decreased by a turnover and a respiration term. LAI is inferred from the leaf biomass multiplied by the specific leaf area ratio, which depends on the leaf nitrogen concentration (Calvet and Soussana, 2001; Gibelin et al., 2006). A more complex version of the model is able to describe the wood biomass and carbon storage (Gibelin et al., 2008). The latter is not used in this study as is has no impact on the LAI and on the plant transpiration simulated by the simpler version. Note that LAI can be either simulated by the model or prescribed to the model using the ECOCLIMAP look-up tables.

\subsubsection{The TRIP river routing model}

TRIP was developed at the Tokyo University by Oki and Sud (1998) and was recently coupled to the SURFEX system (Decharme et al., 2010). TRIP converts the daily runoff simulated by ISBA or ISBA-A-gs into river discharges. It is a simple linear model based on two prognostic equations for the water mass within each grid cell of the hydrological network (Decharme et al., 2010). TRIP takes into account a simple groundwater reservoir, which can be seen as a simple soil-water storage, and a variable stream flow velocity as proposed by Arora and Boer (1999). The groundwater outflow is linearly related to the groundwater mass, $G$, through a uniform and constant time delay factor, $t$. Changes in the $G$ reservoir do not represent the groundwater dynamics, but permit the representation of the lagged contribution of the groundwater flow to the surface river reservoir within a particular grid cell: while the surface runoff produced by ISBA directly supplies the rivers, the deep drainage produced by ISBA is first injected into the groundwater reservoir. In this study, the latter supplies the rivers with a time delay factor of $t=30$ days. The TRIP river parameters (slopes, river width and length, etc.) are provided at a spatial resolution of $0.5^{\circ}$. They are the same as those described in Decharme et al. (2010) at a $1^{\circ}$ grid cell resolution.

\subsubsection{Experimental design}

The simulations performed in this study are produced by SURFEX version 6.2. SURFEX is driven by the 3-hourly meteorological data described in Sect. 2.1, for the 1991-2008 period, at a $0.5^{\circ}$ grid resolution. The year 1991 is run three times in order to spin up the simulations. The simulations 
are based on the ECOCLIMAP-II (Faroux et al., 2009) land cover map. The ERA-I-RG precipitation data are used to force the three configurations of the ISBA LSM. Hereafter, the simulations performed by the standard version of ISBA are referred to as "STD" (see Table 1). ISBA-A-gs is used in the two following configurations (Table 1):

- The annual cycle of LAI is provided by ECOCLIMAPII as a fixed satellite-derived climatology, as for STD simulations. This simulation is referred to as "AST" (Ags and the enhanced soil moisture stress option).

- ISBA-A-gs simulates daily LAI values. This simulation is referred to as "NIT" (with a nitrogen dilution-based representation of leaf biomass, in addition to the AST capability).

The used global river channel network of the ISBA-TRIP system has a spatial resolution of $0.5^{\circ} \times 0.5^{\circ}$. The comparison between AST-TRIP and NIT-TRIP permits the assessment of the impact of differences in the seasonal and interannual variability of LAI on the river discharge simulations. Indeed, the same representation of biophysical processes and the same tiling approach are used in AST and NIT simulations, except for constrained and unconstrained LAI. On the other hand, the comparison between STD-TRIP and AST-TRIP permits the benchmarking of ISBA and ISBAA-gs evapotranspiration fluxes, because the two simulations use the same LAI climatology and the same tiling approach. As a component of the hydrological cycle, evapotranspiration influences the soil moisture dynamics and the water flux from the LSM to the TRIP river routing scheme. Therefore, while comparing the GRDC observations with the TRIP river discharge simulations forced by STD and AST permits the assessment of the contrasting transpiration parameterization used in ISBA and in ISBA-A-gs, the use of NIT allows the evaluation of the LAI simulated by ISBA-A-gs.

\subsection{Comparison between observed and simulated river discharges}

In this study, river discharge simulations are obtained from (1) NIT-TRIP driven by the four different precipitation data sets (ERA-I, ERA-I-R, ERA-I-G, ERA-I-RG) described in Sect. 2.1.2, and (2) STD-, AST-, NIT-TRIP driven by ERA-IRG. The simulations are compared with the available GRDC river discharge observations.

The comparison of the various precipitation data sets permits the determination of:

- the precipitation impact on the river discharge simulations (a model sensitivity study);

- the best precipitation data set to drive the coupled LSMTRIP model; and
- the usefulness of rescaling ERA-I twice (first with GPCP and second with GPCC) vs. rescaling ERA-I once with GPCC.

Observed and simulated river discharge $(Q)$ data are generally expressed in $\mathrm{m}^{3} \mathrm{~s}^{-1}$. As the observed drainage area may differ slightly from the simulated one, scaled Q-values in $\mathrm{mm} \mathrm{d}^{-1}$ (the ratio of $Q$ to the drainage area) are used in this study. This permits the direct comparison of $Q$ with precipitation and evaporation values, both expressed in $\mathrm{mm} \mathrm{d}^{-1}$.

Different hydrological skill scores (Krause et al., 2005) can be used in order to assess to what extent the simulations are close to the GRDC observations. Four scores are used in this study:

- the annual discharge ratio criterion, $\overline{Q_{\text {sim }}} / \overline{Q_{\text {obs }}}$, where $\overline{Q_{\text {sim }}}$ and $\overline{Q_{\text {obs }}}$ represent the mean simulated and observed river discharges, respectively;

- the root mean square difference (RMSD) between GRDC observations and the simulated Q-values, based on scaled monthly anomalies (dimensionless); and

- the square correlation coefficient $\left(r^{2}\right)$, based on daily time series, and the efficiency skill score (Eff) defined as the Nash criterion (Nash and Sutcliffe, 1970) that measures the model ability to capture the daily discharge dynamics.

The latter is defined as:

$\mathrm{NASH}=1-\frac{\sum\left(Q_{\text {sim }}(t)-Q_{\mathrm{obs}}(t)\right)^{2}}{\sum\left(Q_{\mathrm{obs}}(t)-\overline{Q_{\mathrm{obs}}}\right)^{2}}$,

where $\overline{Q_{\text {obs }}}$ represents the observed mean Q-value. The best Eff value is 1 , for a perfect simulation. The Eff coefficient can be negative if the simulated $Q$ is very poor and is above 0.5 for a fair simulation (Boone et al., 2004; Decharme et al., 2006). A value of 0 indicates that the predictions of the system are as accurate as using the mean of the observed data. Negative values occur if the observed mean is a better predictor than the system output.

The scaled $Q$ anomalies used in the computation of the RMSD score (or z-score) are defined as:

$z(\mathrm{mo}, \mathrm{yr})=\frac{Q(\mathrm{mo}, \mathrm{yr})-\operatorname{avg}(Q(\mathrm{mo},:))}{\operatorname{stdev}(Q(\mathrm{mo},:))}$,

where $z$ (mo,yr) and $Q$ (mo,yr) are, respectively, the anomaly and the $Q$ for the month mo and the year $\mathrm{yr}$; and $\operatorname{avg}(Q(\operatorname{mo},:))$ and $\operatorname{stdev}(Q(m o,:))$ are the average and the standard deviation of the $Q$ of the month mo, for all years, respectively.

The various ISBA-TRIP simulations can be compared using average score values and their range. As the statistical distribution of the scores may differ from one simulation to another, and across stations, the analysis of the cumulative distribution functions (CDF) of the scores is useful, 
also. Finally, the seasonal changes in the performance of a given simulation can be assessed by calculating the scores month by month, across the $18 \mathrm{yr}$, and the fraction of stations presenting a score value within a predefined range. In this study, we used $[0.5,1]$ and $[0.8,1.2]$ for Eff and $\overline{Q_{\text {sim }}} / \overline{Q_{\text {obs }}}$, respectively. The seasonal monthly scores of the stations (see Figs. $8,9,10$ ) are derived from daily values and determined using a moving window of three months (the previous and following months are included in the score calculation). The number of daily Q-values used in the calculation of these scores varies from 1602 to 1656 ( 3 months $\times 18$-yr). It must be noted that all the scores are based on daily values, except for RMSD, which is based on monthly anomaly values (Eq. 3).

\section{Results}

This section presents the impact of using different (1) precipitation fields and (2) versions of the ISBA LSM on the quality of the river discharge simulations of ISBA-TRIP over the CNF domain for the 1991-2008 period. The climatology covering the MBS domain is used in the Discussion, Sect. 4.

\subsection{Correction of ERA-I precipitation}

Figure 3 shows a comparison of the original monthly ERA-I and ERA-I-R precipitation estimates with the GPCC monthly data product, in terms of bias and temporal correlation. The $r^{2}$ score calculation is based on 216 monthly precipitation values corresponding to the 1991-2008 period. The correlation between ERA-I and GPCC is good $\left(r^{2}>0.6\right)$ over a large part of Europe, and poor or non-significant around the Caspian Sea and (at the south of the domain) from the Sahara arid areas to Irak. ERA-I-R correlates better with the GPCC monthly product than the initial ERA-I precipitation for a large part of the considered area and particularly over Europe. Very good $\left(r^{2}>0.8\right)$ correlations are obtained over a large part of the domain. The $r^{2}$ values tend to decrease in coastal areas, and while good correlations are observed over the Middle East and in North Africa, non-significant correlations are still obtained close to the Caspian Sea and in the Sahara desert where precipitation is close to zero. It can be noted that these regions are characterized by a low station cover (Fig. 1), affecting the quality of the GPCC product. An attempt was made (not shown) to remove the annual cycle from the precipitation time series. This had no impact on the $r^{2}$ maps. Regarding the biases, the GPCP rescaling of ERAI-R tends to increase the precipitation values, thus reducing the marked precipitation underestimation of ERA-I. Over the whole domain, the underestimation is about $20 \%$ for ERAI and $6 \%$ for ERA-I-R. However, the relative increase in the ERA-I-R precipitation, relative to ERA-I, is excessive for some coastal regions where a marked overestimation of the precipitation is observed. In Northern Europe, and in a
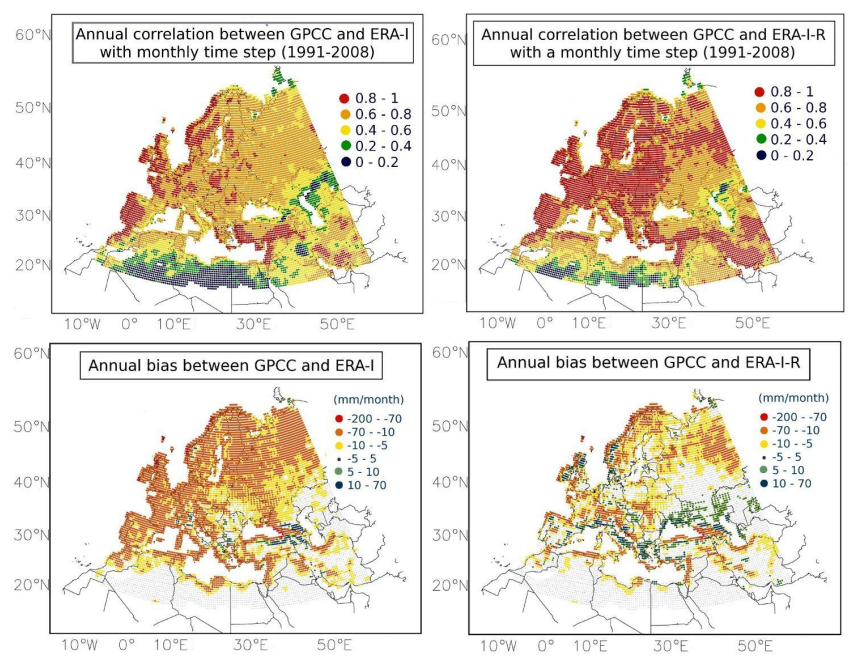

Fig. 3. Monthly scores of the ERA-I and ERA-I-R precipitation estimates with respect to GPCC, over the 1991-2008 period: (left panel) ERA-I and (right panel) ERA-I-R in terms of (top panel) temporal correlation $\left(r^{2}\right)$ and (bottom panel) mean bias.

number of mountainous areas (the Pyrenees, the Alps, the French Massif Central, the Carpathians, the Caucasus Mountains), the ERA-I-R precipitation is still underestimated in comparison to the monthly GPCC product. It must be noted that the hybrid 3-hourly ERA-I-G and ERA-I-RG products are based on the GPCC monthly data (through Eq. 1) and as such are completely bias-corrected and perfectly correlated with GPCC on a monthly basis. However, the 3-hourly precipitation temporal distributions of ERA-I-G and ERA-I-RG differ slightly. In the following section, the impact of differences in the precipitation forcing on the $Q$ simulations of the coupled ISBA-A-gs/TRIP model is investigated.

\subsection{Impact of precipitation on the simulated CNF river discharge}

The verification of the daily discharge simulations is based on the 150 GRDC stations of the CNF domain. Figure 4 presents the CDFs of the Eff score and of the departure of the $\overline{Q_{\text {sim }}} / \overline{Q_{\text {obs }}}$ ratio from 1 for the NIT-TRIP simulations forced by ERA-I and for the three rescaled versions of the precipitation forcing (Table 1). For both scores, the rescaled ERA-I precipitation versions provide much better results than the original ERA-I. In particular, the GPCC correction based on Eq. (1) provides the best results. For ERA-I, ERA-I-R, ERAI-G, and ERA-I-RG, the fractions of the $150 \mathrm{CNF}$ GRDC stations presenting a Eff score greater than 0.5 are $11 \%$, $30 \%, 50 \%$ and $52 \%$, respectively. Similar results are found (not shown) using STD-TRIP or AST-TRIP instead of NITTRIP. Overall, the ERA-I-RG simulations provide the best results, and the ISBA-TRIP simulations described below are all based on the ERA-I-RG precipitation data. 

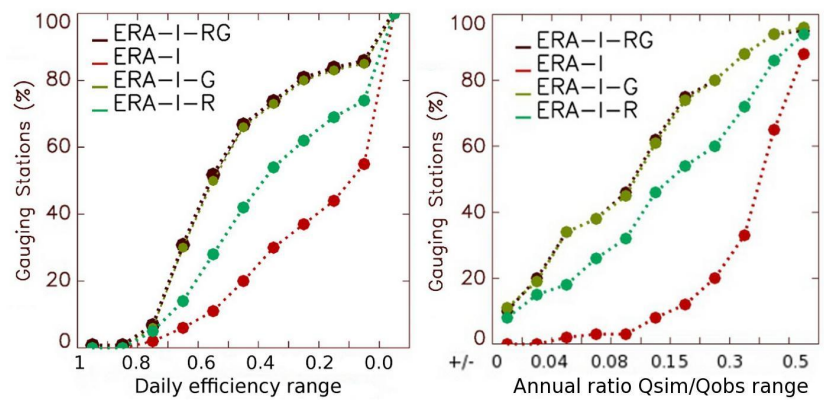

Fig. 4. Cumulative distributions of the (left) Eff score and (right) $\left|1-\overline{Q_{\text {sim }}} / \overline{Q_{\text {obs }}}\right|$ values of daily river discharges simulated by the TRIP model driven by the NIT LSM option for several input precipitation data sets. The black, green, turquoise blue and red lines represent the simulations obtained with ERA-I-RG, ERA-I-G, ERAI-R and ERA-I precipitation, respectively. These distributions are computed from a dense observational network consisting of daily discharges at 150 gauging stations in the CNF area.

\subsection{Impact of changes in the LSM configuration on the simulated CNF river discharge}

In this section, the simulated Q-values obtained with different versions of the ISBA LSM are compared to GRDC gauging measurements. Figure 5 presents the CDFs of the Eff score and of the departure of the $\overline{Q_{\text {sim }}} / \overline{Q_{\text {obs }}}$ ratio from 1 , for the NIT-, STD- and AST-TRIP simulations. The NIT curves of Fig. 5 correspond to the same simulation as the ERA-I-RG curves of Fig. 4 (Table 1). The $r^{2}$ and RMSD CDFs are not shown in Fig. 5 since the NIT, STD, and AST curves are almost confounded (see the corresponding scores in Table 2). The Eff and $\overline{Q_{\text {sim }}} / \overline{Q_{\text {obs }}}$ CDFs present more variability, and show that the NIT- and AST-TRIP simulations perform better than STD-TRIP. Most of the Eff improvement is attributable to bias reduction. For both Figs. 4 and 5, differences in $\overline{Q_{\text {sim }}} / \overline{Q_{\text {obs }}}$ CDFs are consistent with differences in Eff CDFs. The $r^{2}$ CDFs are not shown as all the curves are almost confounded.

Figure 6 shows the spatial distribution of the AST-TRIP Eff score and of the differences between AST-TRIP and the two other simulations over the entire 1991-2008 period. Values of the Eff score better than 0.5 are obtained for a large fraction of the 150 stations: $44 \%, 52 \%$, and $49 \%$ for STD, NIT, and AST, respectively. Inadequate simulations, characterized by negative Eff values, are obtained for $16 \%, 13 \%$, and $13 \%$ of the stations, respectively. For many regions, STD, AST and NIT present similar Eff scores. While NIT presents the best Eff scores over Scandinavia, AST tends to outperform NIT in other regions, for $19 \%$ of the stations (especially in France and in Germany). The AST simulations outperform STD simulations more extensively, for $40 \%$ of the stations (e.g. in Scandinavia, in the Danube basin), while the reverse is true for $2 \%$ of the stations only.
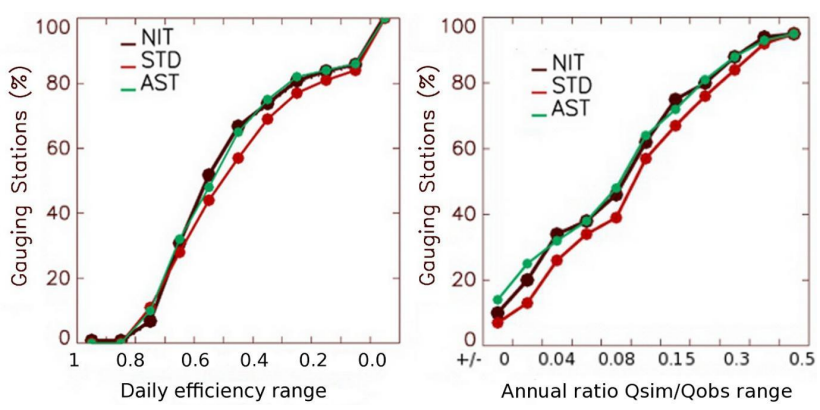

Fig. 5. Cumulative distributions of (left) efficiency and (right) | $1-\overline{Q_{\text {sim }}} \overline{Q_{\text {obs }}}$ | values of daily river discharges simulated with the TRIP model. The black, green and red lines represent the NIT-, AST- and STD-TRIP simulations, respectively, driven by the ERAI-RG precipitation. These distributions are computed from a dense observational network consisting of daily river discharges at 150 gauging stations in the CNF area.

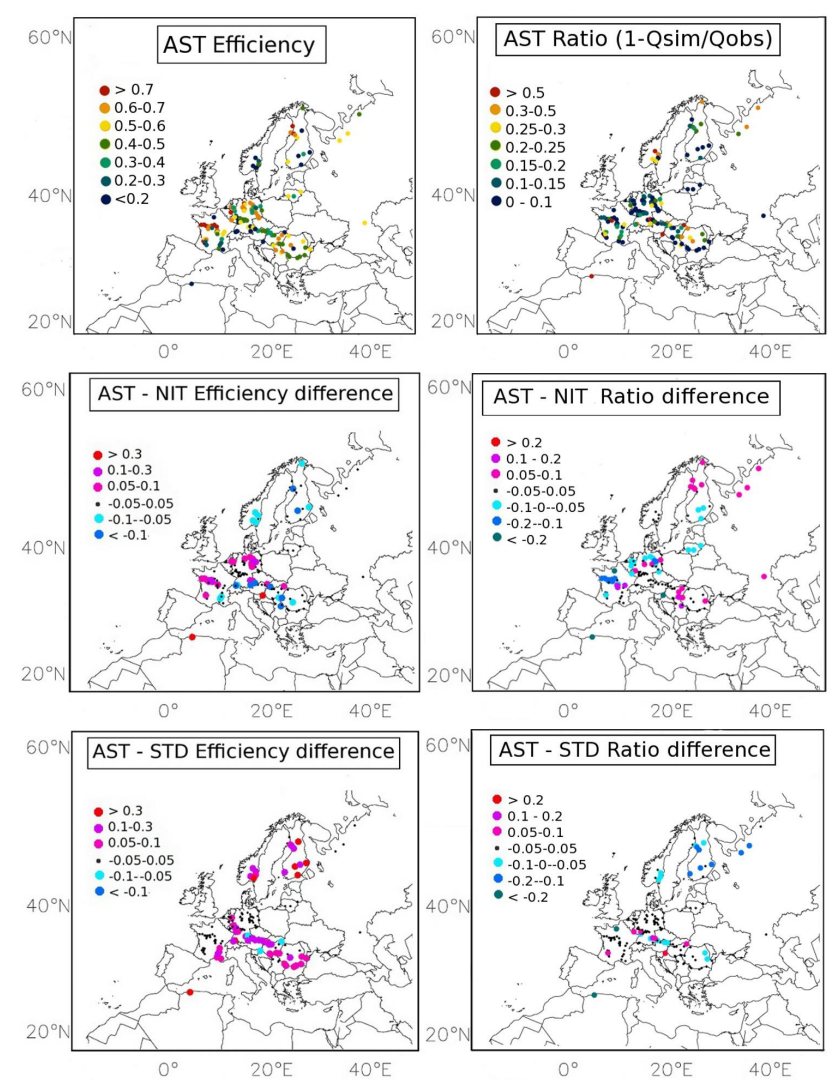

Fig. 6. Comparison between (top panel) AST-TRIP and observed GRDC river discharges in terms of (left panel) Eff scores and (right panel) $\left|1-\overline{Q_{\text {sim }} Q_{\mathrm{obs}}}\right|$ values for the 150 gauging stations of the $\mathrm{CNF}$ area, and (middle panel) differences between AST and NIT scores and (bottom panel) AST and STD scores. Positive difference values correspond to (left panel) better and (right panel) poorer scores. The scores are based on daily values over the 1991-2008 period. 
Table 2. Scores obtained for 16 stations corresponding to the outlet of the largest CNF basins ( $\left.>20000 \mathrm{~km}^{2}\right)$. The Eff, $\overline{Q_{\text {sim }}} / \overline{Q_{\text {obs }}}$, and $r^{2}$ scores are based on daily values. The RMSD score is based on scaled monthly anomalies. Mean annual cycles of each stations are given in Fig. 7. The drainage area considered in the TRIP hydrological model is given together with the name of the river. For each score and each simulation, the best score value is presented in bold.

\begin{tabular}{|c|c|c|c|c|c|c|c|c|c|c|c|c|}
\hline \multirow{2}{*}{ Station } & \multicolumn{3}{|c|}{ Eff } & \multicolumn{3}{|c|}{$\overline{Q_{\mathrm{sim}}} / \overline{Q_{\mathrm{obs}}}$} & \multicolumn{3}{|c|}{$r^{2}$} & \multicolumn{3}{|c|}{ RMSD (stdev units) } \\
\hline & STD & AST & NIT & STD & AST & NIT & STD & AST & NIT & STD & AST & NIT \\
\hline Danube & & & & & & & & & & & & \\
\hline $\begin{array}{l}810966 \mathrm{~km}^{2} \\
\text { Rhone }\end{array}$ & 0.47 & 0.54 & 0.52 & 0.94 & 0.97 & 1.01 & 0.62 & 0.64 & 0.63 & 0.58 & 0.57 & 0.59 \\
\hline $\begin{array}{l}68377 \mathrm{~km}^{2} \\
\text { Chelif }\end{array}$ & 0.12 & 0.25 & 0.29 & 0.76 & 0.80 & 0.83 & 0.61 & 0.62 & 0.61 & 0.47 & 0.47 & 0.46 \\
\hline $\begin{array}{l}42727 \mathrm{~km}^{2} \\
\text { Garonne }\end{array}$ & -5.92 & -5.31 & -6.07 & 8.36 & 7.66 & 8.42 & 0.35 & 0.33 & 0.34 & 0.78 & 0.84 & 0.78 \\
\hline $\begin{array}{l}51122 \mathrm{~km}^{2} \\
\text { Loire }\end{array}$ & 0.62 & 0.65 & 0.67 & 0.70 & 0.72 & 0.74 & 0.65 & 0.66 & 0.65 & 0.45 & 0.45 & 0.45 \\
\hline $\begin{array}{l}112167 \mathrm{~km}^{2} \\
\text { Seine }\end{array}$ & 0.79 & 0.78 & 0.69 & 1.14 & 1.15 & 1.27 & 0.77 & 0.76 & 0.77 & 0.47 & 0.47 & 0.48 \\
\hline $\begin{array}{l}67359 \mathrm{~km}^{2} \\
\text { Meuse }\end{array}$ & 0.66 & 0.67 & 0.64 & 0.98 & 1.00 & 1.02 & 0.80 & 0.80 & 0.79 & 0.39 & 0.38 & 0.41 \\
\hline $\begin{array}{l}31748 \mathrm{~km}^{2} \\
\text { Rhine }\end{array}$ & 0.71 & 0.69 & 0.64 & 1.07 & 1.12 & 1.18 & 0.69 & 0.68 & 0.67 & 0.53 & 0.54 & 0.54 \\
\hline $\begin{array}{l}170702 \mathrm{~km}^{2} \\
\text { Weser }\end{array}$ & 0.33 & 0.36 & 0.32 & 1.01 & 1.05 & 1.09 & 0.48 & 0.48 & 0.47 & 0.53 & 0.53 & 0.54 \\
\hline $\begin{array}{l}40101 \mathrm{~km}^{2} \\
\text { Elbe }\end{array}$ & 0.69 & 0.72 & 0.70 & 0.87 & 0.89 & 0.92 & 0.76 & 0.76 & 0.74 & 0.41 & 0.40 & 0.41 \\
\hline $\begin{array}{l}133895 \mathrm{~km}^{2} \\
\text { Oder }\end{array}$ & 0.69 & 0.69 & 0.60 & 1.09 & 0.86 & 1.18 & 0.74 & 0.74 & 0.73 & 0.47 & 0.48 & 0.48 \\
\hline $\begin{array}{l}105182 \mathrm{~km}^{2} \\
\text { Niemen }\end{array}$ & 0.37 & 0.40 & 0.44 & 0.80 & 0.81 & 0.86 & 0.64 & 0.65 & 0.63 & 0.56 & 0.54 & 0.54 \\
\hline $\begin{array}{l}86551 \mathrm{~km}^{2} \\
\text { Volga }\end{array}$ & 0.52 & 0.56 & 0.51 & 1.00 & 1.02 & 1.09 & 0.69 & 0.70 & 0.67 & 0.64 & 0.60 & 0.64 \\
\hline $\begin{array}{l}1353811 \mathrm{~km}^{2} \\
\text { S. Dvina }\end{array}$ & 0.55 & 0.57 & 0.53 & 0.87 & 0.91 & 1.02 & 0.58 & 0.56 & 0.52 & 0.75 & 0.69 & 0.73 \\
\hline $\begin{array}{l}382746 \mathrm{~km}^{2} \\
\text { Kemijoki }\end{array}$ & 0.56 & 0.55 & 0.53 & 0.66 & 0.78 & 0.87 & 0.75 & 0.69 & 0.63 & 0.74 & 0.72 & 0.72 \\
\hline $\begin{array}{l}55632 \mathrm{~km}^{2} \\
\text { Glama }\end{array}$ & 0.54 & 0.69 & 0.71 & 0.73 & 0.84 & 0.90 & 0.77 & 0.76 & 0.74 & 0.65 & 0.65 & 0.65 \\
\hline $22089 \mathrm{~km}^{2}$ & 0.42 & 0.51 & 0.52 & 0.91 & 0.96 & 1.00 & 0.66 & 0.67 & 0.69 & 0.54 & 0.53 & 0.52 \\
\hline
\end{tabular}

Also, Fig. 6 presents the departure of the $\overline{Q_{\text {sim }}} / \overline{Q_{\text {obs }}}$ ratio from 1 for the AST-TRIP simulations and the differences between AST-TRIP and the other simulations. While a majority of stations $(63 \%, 61 \%$ and $57 \%$ for AST, NIT and STD, respectively) present a good score $\left(0.85<\overline{Q_{\text {sim }}} / \overline{Q_{\text {obs }}}<\right.$ $1.15)$, a significant fraction of the stations $(18 \%, 19 \%$ and $24 \%$, respectively) do not perform well $\left(\overline{Q_{\text {sim }}} / \overline{Q_{\text {obs }}}<0.7\right.$ or $\overline{Q_{\text {sim }}} / \overline{Q_{\text {obs }}}>1.3$ ). Consistent with the Eff criterion, AST tends to perform better than NIT in France and in Germany, and better than STD in Scandinavia. For all the model versions, the median RMSD value is 0.57 (Table 2). The 10th and 90th percentile values are 0.47 and 0.80 , respectively. The stations presenting RMSD values higher than 0.8 are found in France, upstream of the Garonne, Loire, and Rhone rivers, in Scandinavia, and in Algeria.

Figure 7 shows the mean monthly values of the observed and simulated Q-values for the downstream stations of the largest CNF basins $\left(>20000 \mathrm{~km}^{2}\right.$ ). In the case of the Rhone river, the Viviers station is used instead of the downstream Beaucaire station, as there is a great deal of water extraction between Viviers and Beaucaire. Also, the Durance river is a major tributary of the Rhone upstream Beaucaire and is markedly influenced by dams (Boone et al., 2004).

The Russian Pechora and Mezen rivers are not shown because they present results very similar to those obtained for the Severnaya Dvina river. Table 2 details the different scores (Eff, $\overline{Q_{\text {sim }}} / \overline{Q_{\text {obs }}}$ ratio, $r^{2}$, RMSD) of the STD, AST, and NIT 

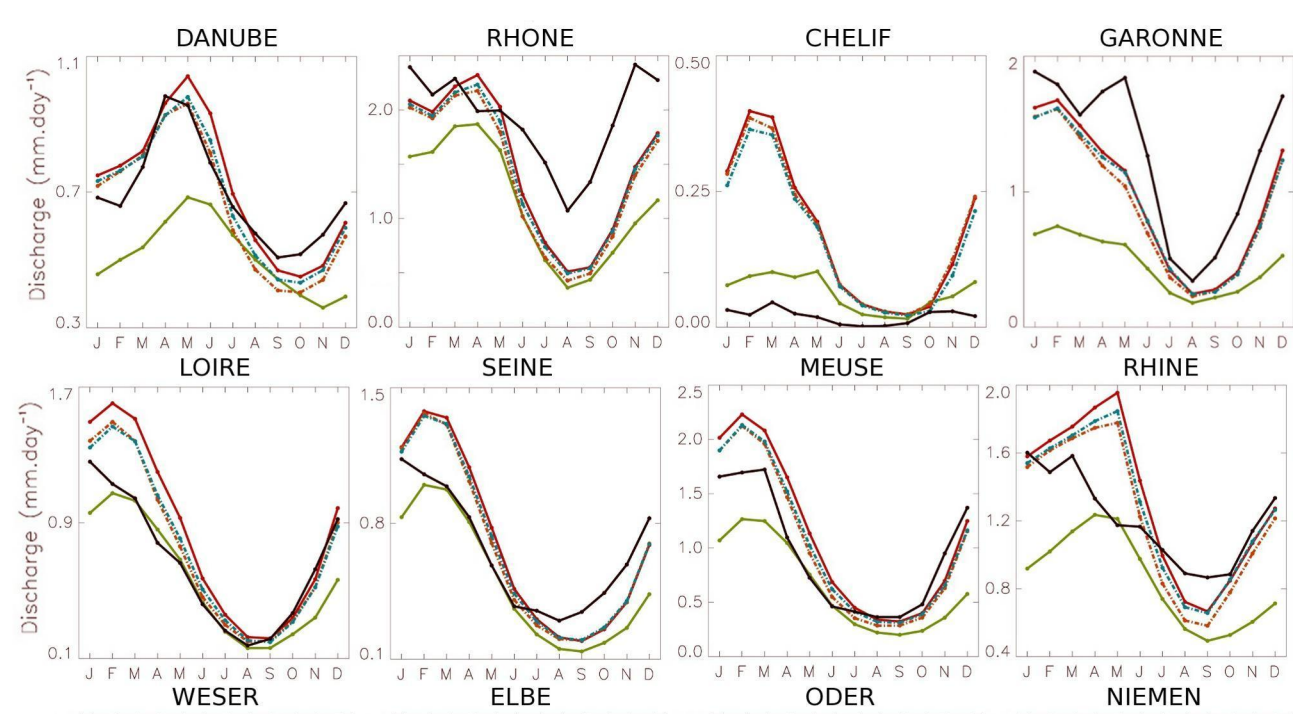

RHINE
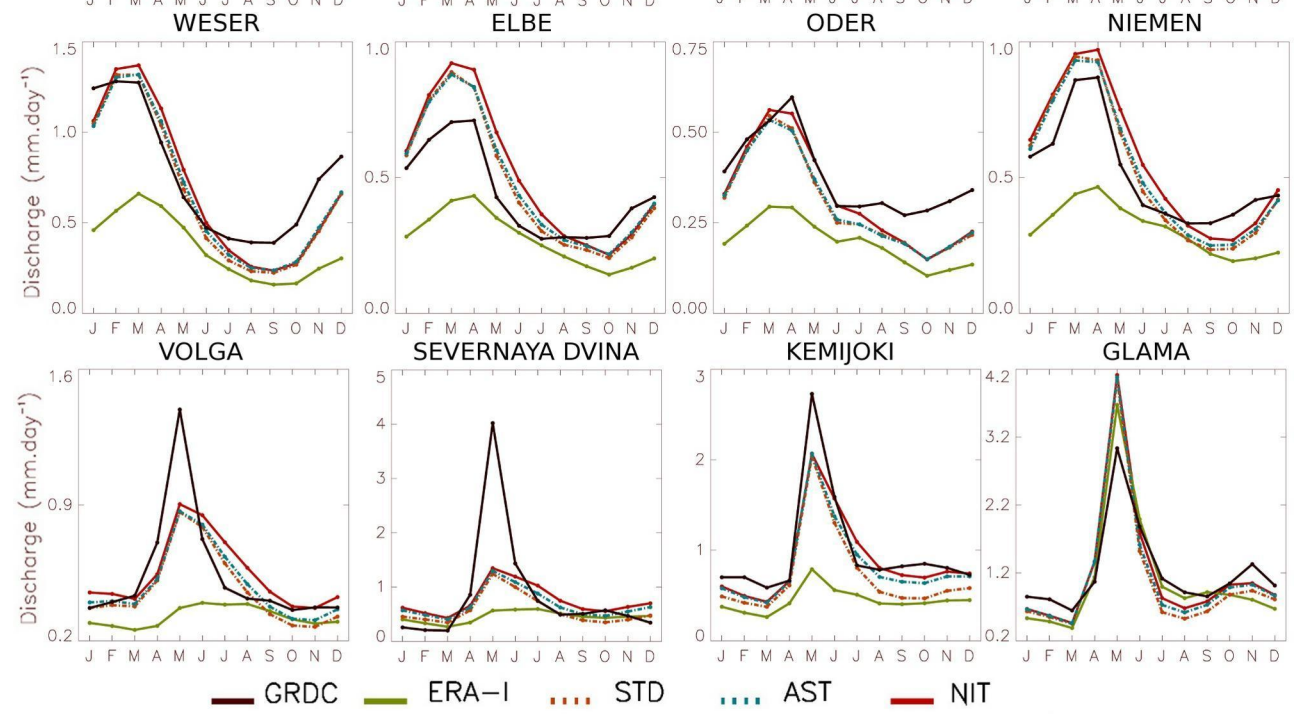

Fig. 7. Comparison of the mean river discharge annual cycles, (coloured lines) simulated and (dark lines) observed (GRDC) at the outlets of the main rivers of the CNF area (red dots in Fig. 1) over the 1991-2008 period. The NIT and ERA-I simulations correspond to NIT-TRIP driven by ERA-I-RG and ERA-I, respectively. The STD and AST simulations correspond to STD-TRIP and AST-TRIP driven by ERA-I-RG, respectively.

simulations for the 16 rivers of Fig. 7. Figure 7 shows that, in general, ERA-I tends to underestimate $Q$, except for the Chelif station (Algeria), which is influenced by dams. On the other hand, NIT tends to simulate the largest Q-values, during all seasons. At low water levels, STD produces the lowest Q-values. Table 2 shows that the RMSD and $r^{2}$ scores do not vary much from one version of the LSM to another. The differences in RMSD values between AST and NIT and between AST and STD are smaller than 0.02 for $85 \%$ and $91 \%$ of the 150 stations, respectively. Differences higher than 0.03 are observed for $5 \%$ of the stations only.

As Fig. 7 and Table 2 show that the Eff and $\overline{Q_{\text {sim }}} / \overline{Q_{\text {obs }}}$ scores respond to changes in LSM and that the quality of the simulations may vary from one season to another, a seasonal analysis was performed using all the CNF stations. These scores are also presented in Fig. 8 on a monthly basis for a moving window of three months in order to highlight the seasonal features. It is shown that the performance of a given simulation with respect to the others varies from one month to another. In March-April-May, STD presents good Eff and $\overline{Q_{\text {sim }}} / \overline{Q_{\text {obs }}}$ scores for a larger fraction of stations than the AST and NIT simulations. For example, in May, STD, AST, and NIT present Eff values higher than 0.5 for $36 \%, 24 \%$, and $19 \%$ of the stations, respectively. This indicates that, in spring, the unconstrained representation of LAI in NIT-TRIP is detrimental to the river discharge simulation, and has more impact than differences in the calculation of plant transpiration. The opposite result is obtained from August to October, 


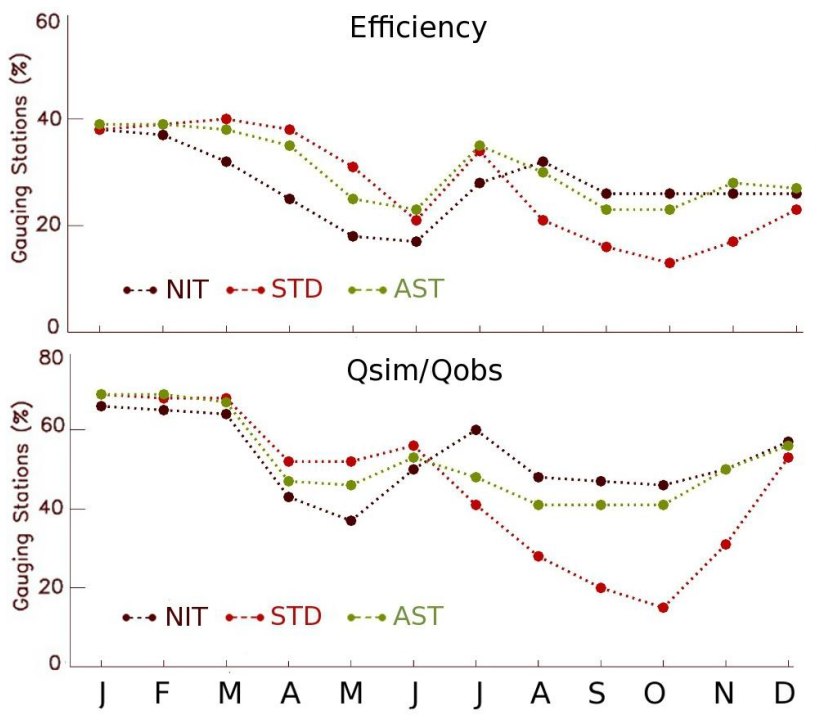

Fig. 8. Monthly percentage of river flow gauging stations presenting (top panel) an efficiency score greater than 0.5 and (bottom panel) a $\overline{Q_{\text {sim }}} / \overline{Q_{\text {obs }}}$ ratio greater than 0.8 and smaller than 1.2 , for NIT-, AST- and STD-TRIP simulations (black, green and red lines, respectively). These distributions are computed from a dense observational network consisting of daily river discharges over the 19912008 period, at the 150 gauging stations of the CNF area.

with STD and NIT presenting the poorest and the best Eff values, respectively. Also, AST performs nearly as well as NIT during this period of the year, indicating that during the autumn the calculation of plant transpiration in STD is detrimental to the river discharge simulation, and has more impact than differences in LAI. The $\overline{Q_{\text {sim }}} / \overline{Q_{\text {obs }}}$ ratio score is particularly good for NIT from August to December, with about $50 \%$ of the stations presenting a $\overline{Q_{\text {sim }}} / \overline{Q_{\text {obs }}}$ ratio close to one, against about $30 \%$ or less for STD-TRIP. An attempt was made (not shown) to reproduce Figs. 4, 5 and 8 considering only one station per basin (closest to the river mouth), i.e. 56 stations instead of 150. For Figs. 4 and 5, exactly the same results were found. For Fig. 8, the differences between the ISBA versions were less marked, but overall the same conclusions were obtained.

Figures 9 and 10 present the seasonal distribution of differences in Eff scores in terms of maps and scatter plots, respectively. The differences are shown for three periods, corresponding to the March-April-May, June-July-August, and September-October-November 3-monthly windows in Fig. 8, and for three model pairs: AST vs. STD, AST vs. NIT, and NIT vs. STD. Since AST and STD share the same representation of LAI (derived from ECOCLIMAP-II), large differences between AST and STD in Fig. 9 correspond to the regions where changes in the description of the transpiration processes impact the water balance and the Q-values. Overall, better results are obtained with AST, except for April, with 85 stations presenting better results with STD. A large fraction of the latter (79\%) is found in Germany. Since AST and NIT share the same representation of plant transpiration, the differences between AST and NIT $Q$ simulations show the impact of LAI. More often than not, the impact of constraining LAI with ECOCLIMAP-II is either moderate or changes (from positive to negative or vice versa) from one period to another. For the French Loire stations and one Garonne station, AST presents systematically better results than NIT. On the other hand, NIT always outperforms AST in Norway. While NIT tends to outperform STD in July and October, the reverse is true in April. For the French Loire and Garonne stations, STD presents systematically better results than NIT, across seasons. For a given river gauging station, Fig. 10 shows both the Eff score values and their differences from one simulation to another. This permits the analysis of the impact of the quality of the simulations on the Eff differences. In general, the few stations presenting the best Eff scores do not present marked differences from one simulation to another. Figure 10 shows that AST and NIT tend to systematically outperform STD during the autumn.

\subsection{Impact of changes in the LSM configuration on the simulated MBS river discharge}

The monitoring of hydrological drought events over Mediterranean regions is more challenging. Because no GRDC data is available over the 1991-2008 period for the MBS domain, no detailed study could be performed over this area. However, the modelled monthly climatology of river discharges could be compared with the climatology derived from the past in situ observations of the MBS domain. Figure 11 presents the mean monthly river discharge climatology over the 12 MBS stations listed in Fig. 2, derived from the ISBATRIP simulations over the 1991-2008 period and from the GRDC derived climatology. The chosen MBS stations are as close as possible to the outlet of the main hydrological basins. In general, the three simulations are more similar than for the CNF rivers of Fig. 7, particularly at low water levels. In Italy (Po and Tiber) and in Spain (Ebro, Guadalquivir, and Duero), the differences in simulated Q-values are more marked in spring. The best simulations are obtained for the Spanish rivers and for the Greek Aliákmon river. The ISBATRIP simulations markedly underestimate $Q$ for both springtime and summertime for the Po and Tiber rivers, and for the Turkish Sakarya and Ceyhan rivers. On the other hand, the modelled $Q$ is overestimated for North African rivers (the Tafna and Sebou rivers).

\section{Discussion}

\subsection{Impact of changes in the LSM configuration on LAI, evapotranspiration and total runoff}

Figures 5-11 show that the impact of changes in LSM is rather complex and varies from one region to another and 


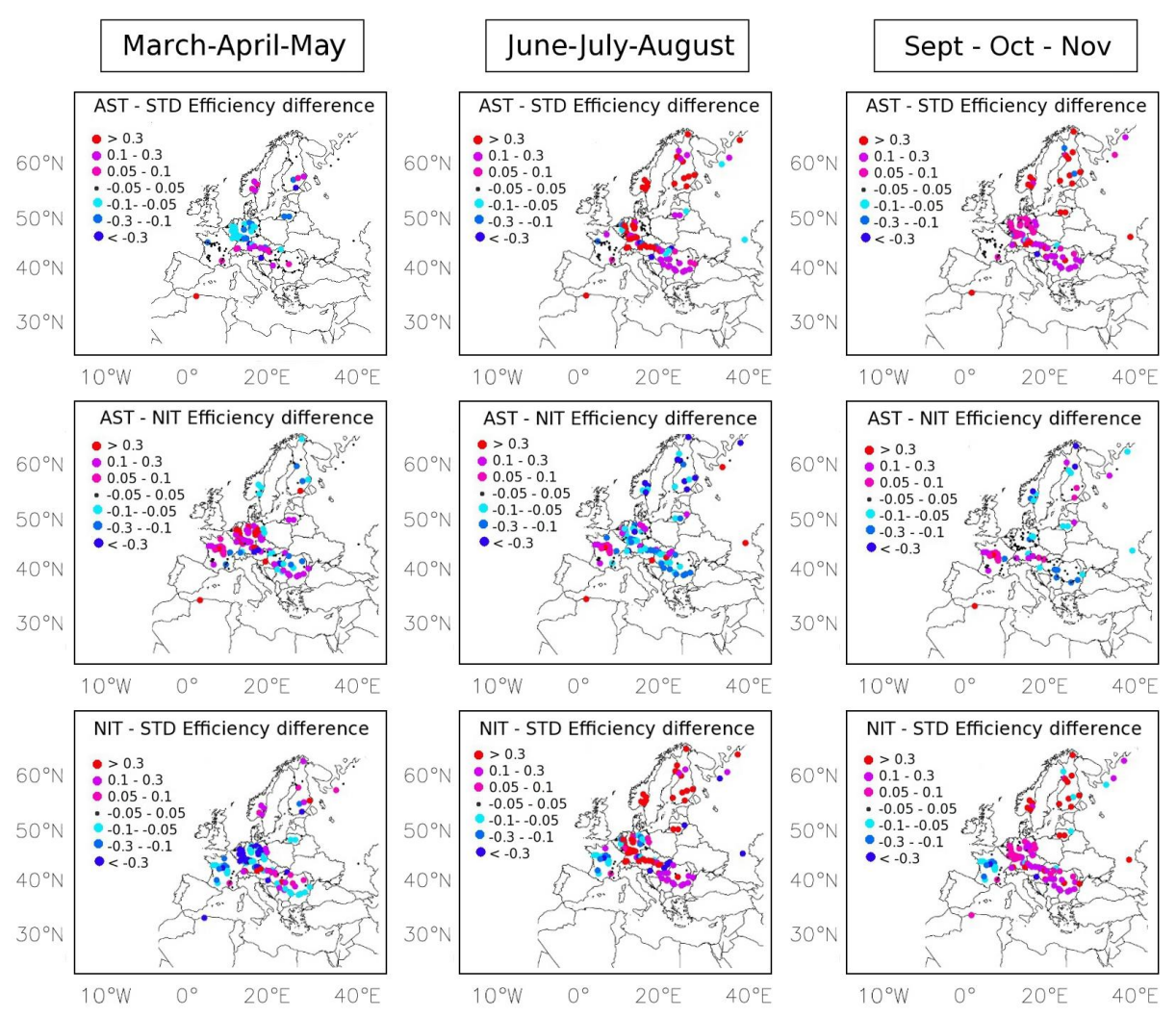

Fig. 9. Seasonal and model breakdown of river flow Eff differences over the CNF area, over the 1991-2008 period. From left to right: spring, summer and autumn. From top to bottom: AST minus STD, AST minus NIT, and NIT minus STD.

from one season to another. Overall, AST performs better than STD, especially over Western Europe; NIT performs better than AST at northern latitudes and over European mountainous areas (Figs. 6 and 9). At summertime and during the autumn only, NIT tends to perform better than the other model options, except for the Loire and Garonne rivers. This is the result of the interplay between the various representations of LAI (either constrained by ECOCLIMAP-II or predicted by the model) and stomatal conductance (either related to photosynthesis or based on the standard ISBA parameterization). In order to analyze these interactions, Fig. 12 presents the seasonal (spring, summer and autumn) differences of the three versions of ISBA, in terms of evapotranspiration, total runoff, and simulated (NIT) or prescribed (AST and STD) LAI. The total runoff represents the sum of the surface runoff and of the deep drainage. Over the CNF domain, the prescribed ECOCLIMAP-II LAI values used by AST and STD tend to be greater in spring (from March to May) than the values produced by NIT, while the reverse is observed for the MBS regions. The underestimation of the modelled CNF springtime LAI is consistent with the delay in the simulated leaf onset noticed by Brut et al. (2009) and Lafont et al. (2012) over France. For the same period, the differences in evapotranspiration between AST and NIT present spatial patterns similar to those obtained for differences in LAI. A direct consequence is that the AST total runoff is smaller than the NIT one over the CNF domain (by about $0.1 \mathrm{~mm} \mathrm{~d}^{-1}$ on average), and more particularly in Ireland and in the Alps $\left(\sim 0.4 \mathrm{~mm} \mathrm{~d}^{-1}\right)$. Therefore, the larger LAI values used by STD and AST in spring tend to increase the evapotranspiration over the CNF domain, decrease total runoff values, and produce low water levels more rapidly than NIT (Fig. 7). The AST vs. STD difference in total runoff, which is not affected by differences in LAI, is relatively small in spring. On the other hand, AST presents markedly greater values of the total runoff than STD at summertime and during the autumn for northern latitudes and mountainous areas covered by forests, in relation to a much lower evapotranspiration summertime flux, triggered by the different parameterization of the stomatal conductance and of the plant response to the water stress. Figure 9 shows that the AST parameterization tends to improve the $Q$ simulation over these regions, especially during the autumn. At summertime, NIT LAI values lower than ECOCLIMAP-II LAI values are observed in Russia, in Scandinavia, in Italy and in Greece. On the other hand, the NIT LAI is greater in the Pyrenees, the Alps, the Carpathians, and in the Caucasus Mountains. These differences do not have a marked impact on the total runoff, 

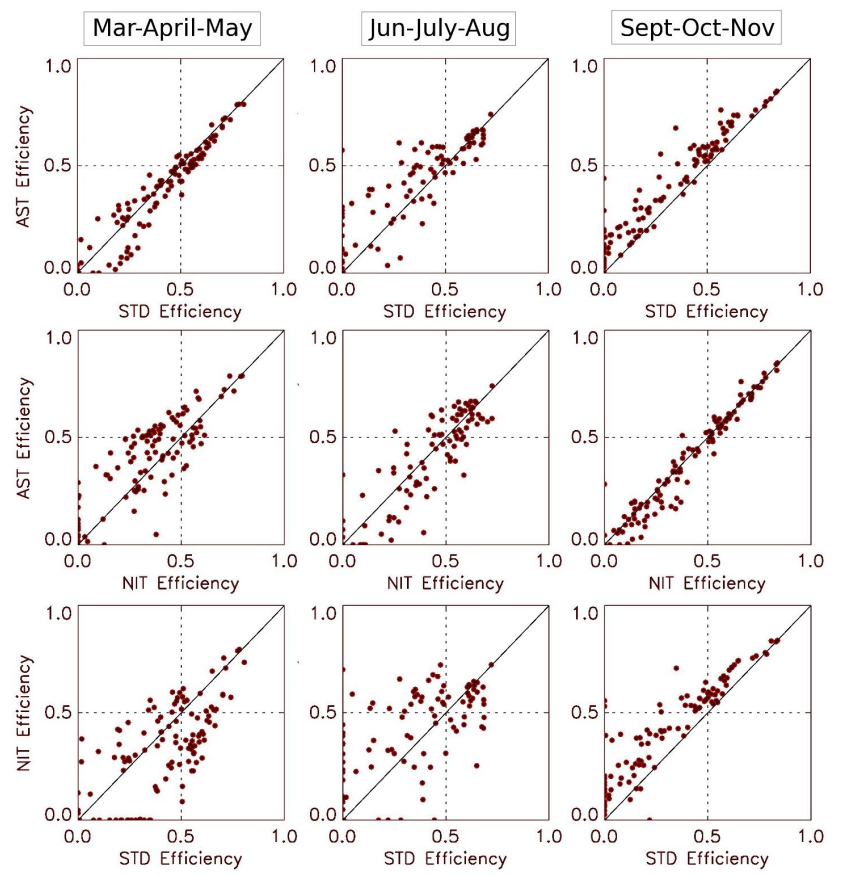

Fig. 10. Seasonal intercomparison of the various LSM-TRIP simulations over the CNF area through scatter-plots of river flow Eff values over the 1991-2008 period: (top panel) AST vs. STD, (middle panel) AST vs. NIT, and (bottom panel) NIT vs. STD. From left to right: spring, summer and autumn. Negative Eff values are represented by 0 .

except for the northern part of the CNF domain. Using a different hydrological model, Queguiner et al. (2011) have also noticed the impact of a late leaf onset over the Alps on the simulated discharges. Finally, Figs. 8 and 10 show that the most significantly different Eff values are observed in autumn, with poorer performance of STD. Deriving general conclusions for the other vegetation schemes is more difficult, as the relative performance of AST vs. NIT vary from one region to another (Fig. 9).

\subsection{Interannual and seasonal variability of the river discharge in the Mediterranean Sea and in the Black Sea}

The simulations performed in this study permit the estimation of the seasonal and annual river freshwater input to the Mediterranean Sea and to the Black Sea. A number of authors have investigated historical Mediterranean river discharge data and analyzed their variability (e.g. Mariotti et al., 2002; Struglia et al., 2004; Ludwig et al., 2009; SanchezGomez et al., 2011). In particular, Ludwig et al. (2009) provide estimates of the river freshwater input to the Mediterranean Sea and to the Black Sea, either observed or reconstructed, for the 1960-2000 period based on a review of the available data on water discharge, nutrient concentrations and climatic parameters. Hereafter, these estimates are

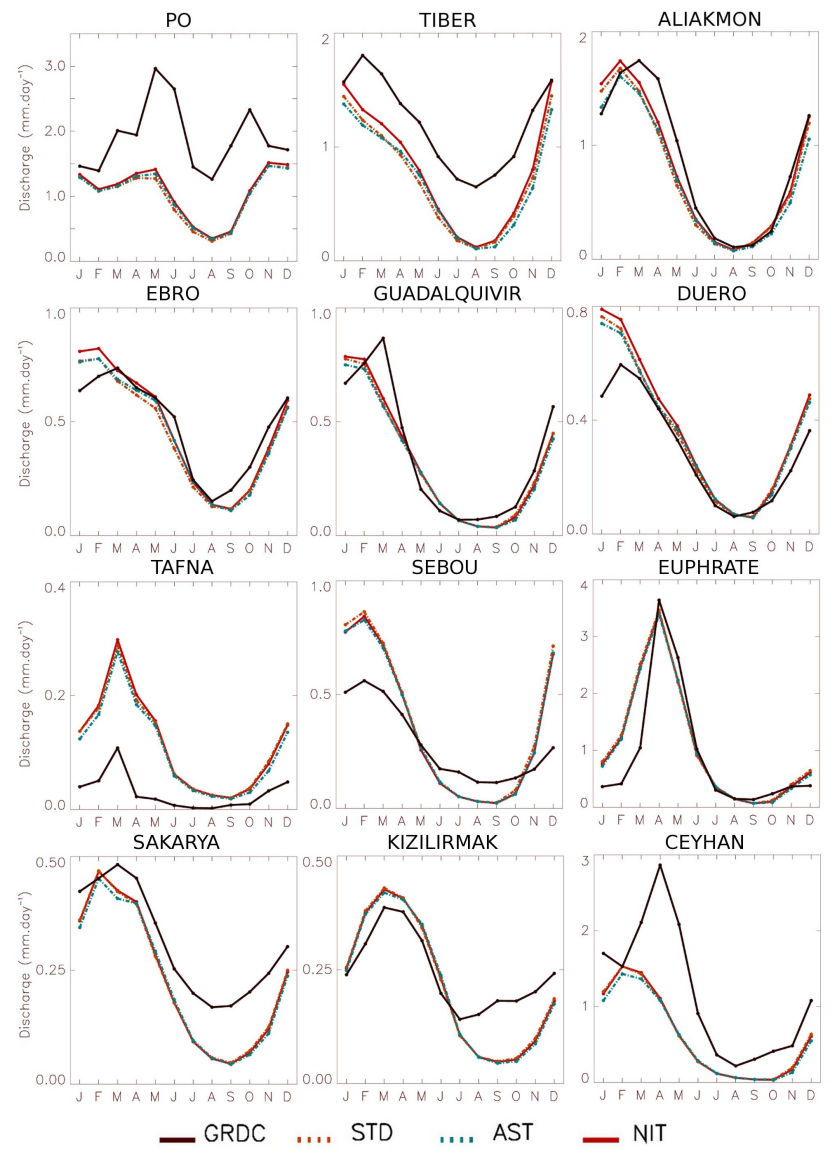

Fig. 11. As in Fig. 7, except for the Mediterranean rivers of the MBS area and historical GRDC climatologies (green dots in Fig. 2). The drainage areas used by TRIP are Po $\left(67519 \mathrm{~km}^{2}\right)$, Tiber $\left(15926 \mathrm{~km}^{2}\right)$, Aliakmon $\left(5005 \mathrm{~km}^{2}\right)$, Ebro $\left(85110 \mathrm{~km}^{2}\right)$, Guadalquivir $\left(48915 \mathrm{~km}^{2}\right)$, Duero $\left(62097 \mathrm{~km}^{2}\right)$, Tafna $\left(7635 \mathrm{~km}^{2}\right)$, Sebou $\left(15392 \mathrm{~km}^{2}\right)$, Euphrate $\left(66923 \mathrm{~km}^{2}\right)$, Sakarya $\left(52509 \mathrm{~km}^{2}\right)$, Kizilirmak $\left(71347 \mathrm{~km}^{2}\right)$, and Ceyhan $\left(22030 \mathrm{~km}^{2}\right)$.

referred to as LDG. The LDG data show that a significant reduction in the discharge of Mediterranean rivers, of at least $20 \%$, occurred during this period in response to climate longterm variability and to the construction of dams. Since the LDG data set overlaps with our simulations, a comparison could be performed. Figure 13 presents the annual river input to the Mediterranean Sea (except for the Nile river discharge), and to the Black Sea, produced by the ERA-I, STD, AST, and NIT simulations, together with the LDG data. Consistent with the results found for the CNF area (Figs. 4 and 7), the ERA-I estimates of $Q$ are underestimated with respect to the LDG 1991-2000 estimates by $40 \%$ for the Mediterranean Sea and by $19 \%$ for the Black Sea. The NIT, AST and STD simulations tend to underestimate $Q$ by $1 \%, 7 \%$ and $6 \%$ for the Mediterranean Sea, and to overestimate $Q$ by $15 \%, 10 \%$ and $9 \%$ for the Black Sea, respectively. While, over the 1991-2000 period, the LDG data correspond to Qvalues of $9895 \mathrm{~m}^{3} \mathrm{~s}^{-1}$ for the Mediterranean Sea (without 


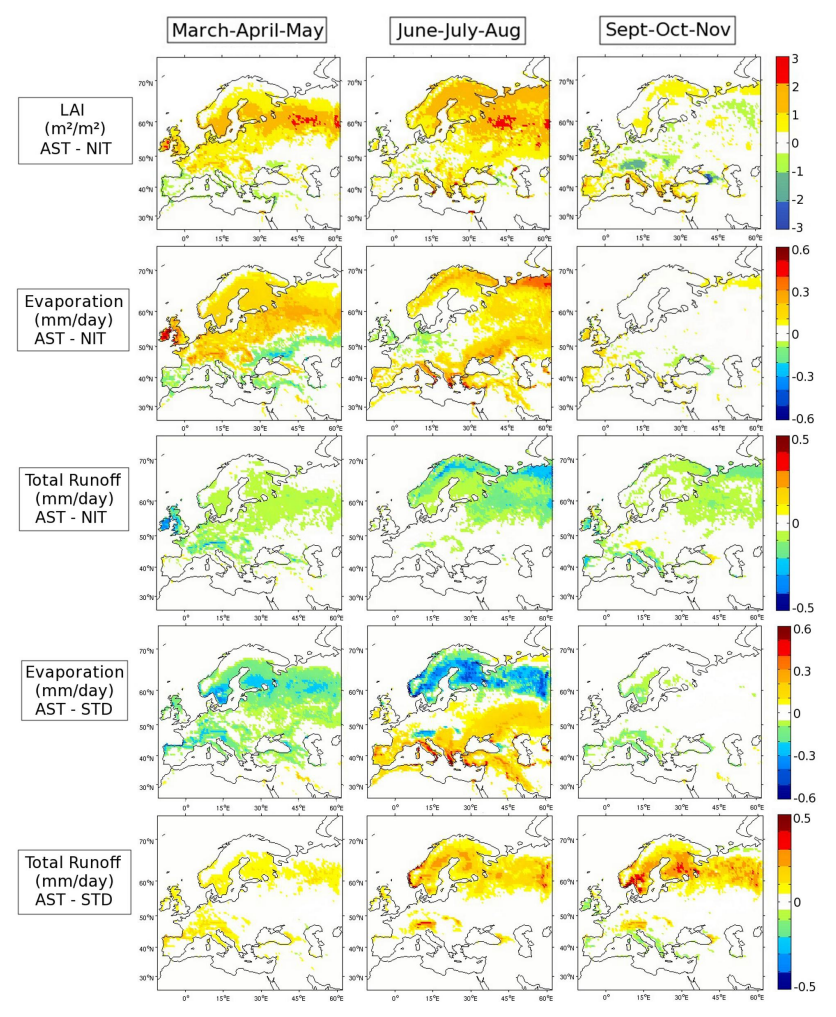

Fig. 12. Seasonal differences in LAI, evapotranspiration and total runoff (surface runoff + deep drainage) of the various LSM-TRIP simulations over the CNF area over the 1991-2008 period. From left to right: spring, summer and autumn. From top to bottom: LAI (ECOCLIMAP-II climatology used in AST and STD minus NIT), evapotranspiration and total runoff (first AST minus NIT, second AST minus STD).

the Nile river) and of $12512 \mathrm{~m}^{3} \mathrm{~s}^{-1}$ for the Black Sea, slightly higher values are obtained with NIT: $10066 \mathrm{~m}^{3} \mathrm{~s}^{-1}$ and $14286 \mathrm{~m}^{3} \mathrm{~s}^{-1}$, respectively. The inter-annual variability is represented well for the Mediterranean Sea, with a correlation significant at the $1 \%$ level. The square correlation coefficients obtained between the LDG mean annual freshwater and the NIT, AST and STD mean annual values are higher than 0.9 for the Mediterranean Sea, and 0.587, 0.582, and 0.556 for the Black Sea, respectively. While the monthly mean annual cycle of the discharges into the Mediterranean Sea is simulated well, the maximum springtime discharges into the Black Sea are markedly underestimated (Fig. 13). The same weakness is found over the Volga basin (Fig. 7) and is triggered by the difficulty in representing snowmelt and thawing processes. It is well known that the wintertime snowfall directly impacts the seasonal cycle of the Northern Russian river discharges. In spring, the runoff triggered by snowmelt over frozen soils is the major contributor to the river stream flow, and simulating this process is not easy (Grippa et al., 2005; Niu and Yang, 2006; Decharme and Douville, 2007; Decharme, 2007). Therefore, the weakness found in this study can be due to an underestimation of the snowfall, a poor snowpack simulation, and/or a poor representation of the surface runoff over frozen soil at the beginning of spring (Niu and Yang, 2006; Decharme and Douville, 2007; Decharme, 2007).

The comparison of the simulations performed in this study with the LDG data set over the 1991-2000 period is illustrated in Fig. 14 for the Ebro, Rhone, Po, and Danube rivers, which represent large basins (of more than $80000 \mathrm{~km}^{2}$ ) for which LDG estimates are based on in situ observations. Consistent with Fig. 7, the Danube discharge is represented relatively well, while the TRIP simulations tend to systematically underestimate the Rhone discharge. In the case of Rhone, the incomplete representation of the topography of the Alps in the low-resolution ERA-I air temperature fields (Szczypta et al., 2011) may explain this result. The simulation of the snow mantel is very dependent on air temperature, and the overestimation of air temperature in mountainous areas tends to reduce the simulated fraction of snow and snow depth. For the basins characterized by upstream mountainous regions, snowmelt has a key influence on the river flow seasonality (Boone et al., 2004; Immerzeel et al., 2009). For the Ebro river, the results differ from those of Fig. 11, as the GRDC data used in the latter correspond to past periods (1913-1935 and 1953-1987). This river is affected by a marked reduction in Q-values. Significant trends for the Ebro river can be derived from the GRDC climatology and from the more recent LDG data: $-0.0041 \mathrm{~mm} \mathrm{yr}^{-1}$ and $-0.0097 \mathrm{~mm} \mathrm{yr}^{-1}$, respectively. In Fig. 14, this negative trend tends to trigger the overestimation of the Ebro Q-values with respect to the LDG estimates (by $48 \%, 39 \%$ and $41 \%$, on average, for NIT, STD and AST, respectively). The latter is related to the rapid development of dams in the Ebro basin (Ludwig et al., 2009), not represented in the TRIP simulations. In the case of Po, the misrepresentation of snow in the Alps can explain the underestimation of Q-values in Fig. 14 (by $22 \%, 25 \%$ and $26 \%$ on average, for NIT, AST and STD, respectively), as for the Rhone.

In Fig. 14, the inter-annual variability of the simulations is represented well for the Danube, Rhone and Po rivers, with $r^{2}$ values of $0.88,0.94,0.57$, respectively, corresponding to significant correlations at the $1 \%$ level for Danube and Rhone, and at the $5 \%$ level for Po. The lack of correlation observed for the Ebro river can be explained by the high fraction of the river discharge (about $40 \%$ on average; Cabezas et al., 2009) used for irrigation.

\subsection{How could the ISBA-TRIP simulations be improved?}

\subsubsection{A better use of land satellite-derived products}

In Sects. 3.3 and 3.4, the importance of the description of the LAI annual cycle is shown. The evapotranspiration at springtime is governed by LAI to a large extent and monthly 

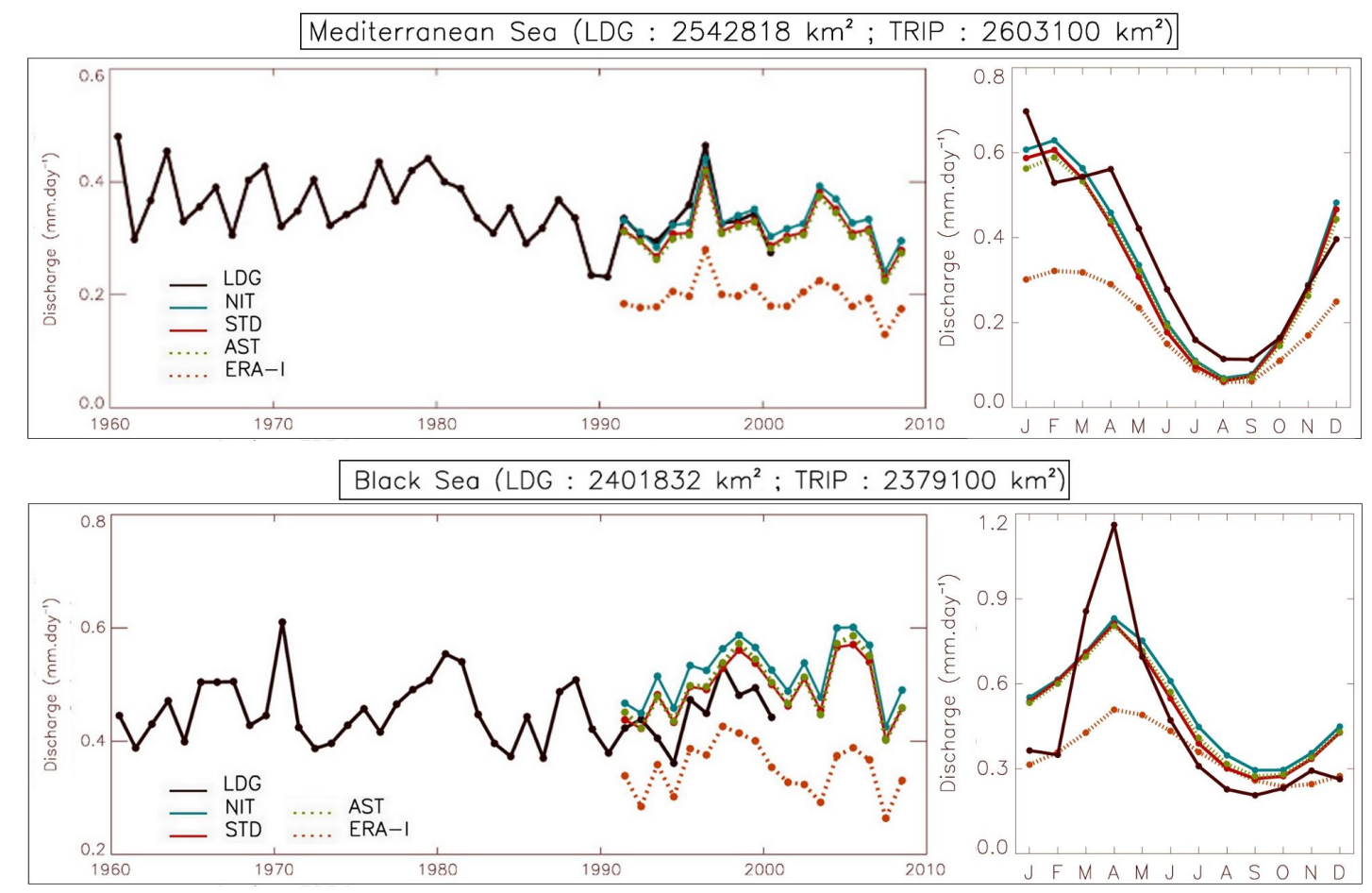

Fig. 13. Total (except for the Nile basin) river freshwater input to (top panel) the Mediterranean Sea, (bottom panel) the Black Sea, as estimated by (dark solid lines) Ludwig et al. (2009) from 1960 to 2000 (LDG), and as simulated in this study (coloured lines) using ERA-I, STD, AST, and NIT from 1991 to 2008: (left panel) annual time series, (right panel) mean annual cycle. The drainage areas used in LDG and in TRIP estimations are given.

or 10-daily LAI time series derived from historical satellite data would be very useful to either evaluate new versions of NIT or force AST simulations. The latter simulations would permit assessing the added value of accounting for the interannual variability of LAI, as the ECOCLIMAP-II LAI data used in this study consist of a fixed seasonal climatology. Also, integrating satellite-derived LAI data in ISBA-A-gs simulations coupled to TRIP, either directly (as in AST simulations) or using more complex data assimilation techniques, as described in Barbu et al. (2011), would be a way to crossvalidate the model and the satellite product, based on the GRDC data. Such a satellite-driven modelling system would be an interesting tool to monitor and to analyze droughts, for example.

\subsubsection{Better precipitation products}

A number of past studies have shown the usefulness of bias-corrected precipitation forcings (e.g. Syed et al., 2004, and Decharme and Douville, 2006b). Using two years of data from the North American Land Data Assimilation System (NLDAS) over the United States, Syed et al. (2004) showed that precipitation dominates the temporal and spatial variability of the hydrological cycle. Decharme and Douville (2006b) quantified the impact of precipitation on river discharge simulations and presented efficiency CDF figures similar to Fig. 4 over the Rhone basin. In Sect. 3.1, it was shown that reducing the ERA-I or ERA-I-R precipitation underestimation using the monthly GPCC data set produces TRIP river discharge simulations as good as those obtained from the hybrid ERA-I-RG precipitation. The ERA-I-RG bias correction presents slightly better results than ERA-I-G. This is due to the better preservation of small scale features of precipitation provided by the GPCP rescaling method of Balsamo et al. (2010). However, the monthly GPCP data set is not available after 2009, and showing that a much simpler bias correction produces nearly equivalent results is encouraging. Also, the downscaling of the GPCC precipitation data, at a spatial resolution better than $10 \mathrm{~km}$ like in the French SAFRAN analysis, could be extended to Europe. Fine scale 2-D and 3-D reanalysis tools are being developed (www.euro4m.eu) and could eventually be used over Europe. Finally, over Northern Black Sea basins, reducing the uncertainty in the snowfall rate estimation is critical. Indeed, the observed snowfall rate is generally underestimated at high latitudes (Adam and Lettenmaier, 2003). Using precipitation gauge catch ratio corrections and accounting for gauge design, wind-induced undercatch and wetting losses would be particularly relevant over Russian basins. 

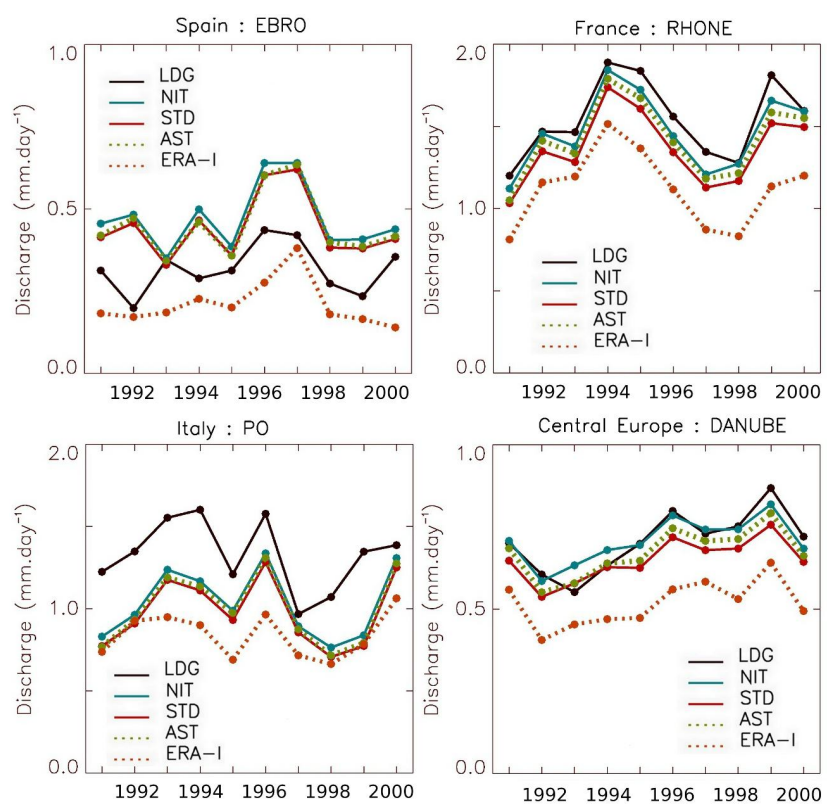

Fig. 14. Comparison of the time series of river discharge simulated in this study (coloured lines) by ERA-I, STD, AST, and NIT, with the observed/reconstructed data set (dark solid lines) of Ludwig et al. (2009), for (from left to right and from top to bottom) the Ebro, Rhone, Po, and Danube large rivers. Note that the total drainage areas considered by TRIP at the outlet of these rivers are $85110 \mathrm{~km}^{2}$, $92733 \mathrm{~km}^{2}, 82905 \mathrm{~km}^{2}, 813140 \mathrm{~km}^{2}$, respectively. These outlet values may be higher than those given in Table 2 or in Fig. 11 for the most downstream inland stations.

\subsubsection{A better representation of the ISBA-TRIP processes}

The LAI values used by the LSM are not the only factors impacting the total runoff. In particular, this study shows that AST simulations, while using the same LAI, tend to perform better than STD simulations, especially for basins covered by forests (Fig. 12). Noilhan et al. (2011) have shown that the evapotranspiration computed with ISBA-A-gs can be improved compared to the standard version of ISBA, at least for forests in southwestern France from April to September. Therefore, efforts to improve the representation of the plant transpiration have a noticeable impact on hydrological simulations. It is likely that further refining the ISBA-A-gs parameterization (e.g. the light interception model) would impact hydrological simulations, also. Another factor affecting the total runoff is the representation of water infiltration and storage into the soil. The force-restore model used in this study is a relatively simple approach, and using the multi-layer soil and snow models available in SURFEX (Boone et al., 2000; Decharme et al., 2011) may impact the conclusions of this study. This explicit approach could be particularly relevant to improve the simulation of soil freezing and thawing and then the discharges over the Northern Black Sea basins. These models have to be implemented jointly, and in the context of large scale river discharge simulations, this configuration is still in the evaluation process. Lafaysse et al. (2011) have shown that improving the sub-grid variability of the snow cover, together with the glacier melt, and the retention of underground water in mountainous areas has a positive impact on hydrological simulations. The enhanced representation of these processes in ISBA should improve the simulation of snowpacks and the river discharge over mountainous areas and high latitudes. Also, for many basins around the Mediterranean Sea, the difficulty in representing the river discharge is mainly due to the presence of dams and to extensive water use for irrigation (e.g. Ebro, Chelif). Future progress in the representation of irrigation and of agricultural practices in ISBA (Calvet et al., 2008, 2012) together with the representation of dams in TRIP (Hanasaki et al., 2006) may help improve the simulations further. Finally, at monthly to seasonal timescales, TRIP can also contribute to systematic errors in the phase and amplitude of river discharge. It could be improved, accounting for large aquifer systems and river flooding. Indeed, a number of studies (Miguez-Macho et al., 2007; Decharme et al., 2010; Vergnes et al., 2012) have shown that the explicit representation of aquifer processes, including groundwater dynamics (storage and redistribution over the whole basin) and the possible evaporation of the deep water via diffusive exchanges with the land surface, impact directly the simulated summer baseflow. In addition, the representation of river flooding is particularly relevant over the Danube basin, where seasonal floodplains are generally observed (Papa et al., 2010). Floodplains contribute to increase the continental evapotranspiration and then to decrease the river discharges during spring and/or the autumn. They also delay and attenuate the river peak flow when the floodplain storage is significant (Decharme et al., 2012).

\section{Conclusions}

River discharge simulations by the coupled ISBA-TRIP system were evaluated in this study. They were driven by surface ERA-I atmospheric variables. The original ERA-I precipitation data set was used together with bias-corrected versions, and with different versions of the ISBA LSM. The river discharge simulations were compared with in situ GRDC observations. Using the GPCC monthly precipitation product to bias-correct the ERA-I precipitation had a pronounced positive impact on the quality of the ISBA-TRIP simulations. Overall, the use of the photosynthesis-based ISBA-Ags LSM options of SURFEX (AST and NIT) slightly improved the river discharge simulations. However, the unconstrained LAI simulations (NIT) tended to reduce the seasonal Eff score in spring. The use of satellite-derived LAI estimates (AST) permitted mitigation of this effect. Over forested mountainous areas and at high latitudes, the summertime evaporation simulated by ISBA (STD) was higher than the evaporation simulated by ISBA-A-gs (AST), and 
tended to dry up the rivers too much in the corresponding drainage areas. Finally, future improvements in the atmospheric forcing and/or in the representation by ISBA-TRIP of biophysical processes should increase the realism of the simulated discharges, especially over northern basins.

Acknowledgements. The work of C. Szczypta was supported by Region Midi-Pyrénées and by Météo-France. This work was performed in the framework of the HYMEX project, and S. Lafont was supported by the GEOLAND2 project, cofunded by the European Commission within the GMES initiative in FP7. River discharge observations were supplied by the Global Runoff Data Centre (Koblenz, Germany). The authors thank Wolfgang Ludwig (CEFREM) and Clotilde Dubois (CNRM-GAME) for providing the data set described in Ludwig et al. (2009) and Gianpaolo Balsamo and Souhail Boussetta (ECMWF) for the ERA-I forcings. The authors wish to thank Christine Delire (CNRM-GAME) together with the three anonymous reviewers for providing many helpful comments.

\section{Edited by: H. Cloke}

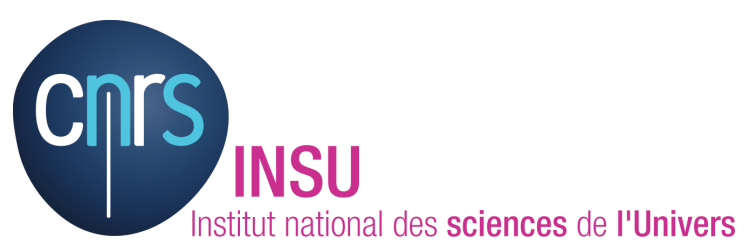

The publication of this article is financed by CNRS-INSU.

\section{References}

Adam, J. C. and Lettenmaier, D. P.: Adjustment of global gridded precipitation for systematic bias, J. Geophys. Res., 108, 4257, doi:10.1029/2002JD002499, 2003.

Adler, R. F., Huffman, G. J., Chang, A., Ferraro, R., Xie, P.-P., Janowiak, J., Rudolf, B., Schneider, U., Curtis, S., Bolvin, D., Gruber, A., Susskind, J., Arkin, P., and Nelkin, E.: The Version-2 Global Precipitation Climatology Project (GPCP) Monthly Precipitation Analysis (1979-present), J. Hydrometeorol., 4, 11471167, 2003.

Arora, V. K.: Modeling vegetation as a dynamic component in soil-vegetationatmosphere transfer schemes and hydrological models, Rev. Geophys., 40, 1006, doi:10.1029/2001RG000103, 2002.

Arora, V. K. and Boer, G. J.: A variable velocity flow routing algorithm for GCMs, J. Geophys. Res., 104, 30965-30979, 1999.

Balsamo, G., Beljaars, A., Scipal, K., Viterbo, P., Van den Hurk, B., Hirschi, M., and Betts, A. K.: A revised hydrology for the ECMWF model: verification from field site to terrestrial water storage and impact in the integrated forecast system, J. Hydrometeorol., 10, 623-643, 2009.

Balsamo, G., Boussetta, S., Lopez, P., and Ferranti, L.: Evaluation of ERA-Interim and ERA-Interim-GPCP-rescaled precipitation over the USA, ERA report series, No. 5, 10 pp., ECMWF, Read- ing, available at: http://www.ecmwf.int/publications/library/do/ references/show?id=89966 (last access: July 2012), 2010.

Barbu, A. L., Calvet, J.-C., Mahfouf, J.-F., Albergel, C., and Lafont, S.: Assimilation of Soil Wetness Index and Leaf Area Index into the ISBA-A-gs land surface model: grassland case study, Biogeosciences, 8, 1971-1986, doi:10.5194/bg-8-1971-2011, 2011.

Barriopedro, D., Fischer, E. M., Luterbacher, J., Trigo, R. M., and García-Herrera, R.: The hot summer of 2010: Redrawing the temperature record map of Europe, Science, 332, 220-224, 2011.

Becker, A.: Development of the GPCC Data Base and Analysis Products, GPCC Annual Report for the year 2009 and 2010, 1-19, DWD, Internet Publication, available at: http://www.dwd.de/bvbw/generator/DWDWWW/Content/ Oeffentlichkeit/KU/KU4/KU42/en/Reports__Publications/ GPCC__annual__report__2009__2010,templateId=raw, property= publicationFile.pdf/GPCC_annual_report_2009_2010.pdf (last access: September 2012), 2011.

Beven, K. J. and Kirkby, M. J.: A physically based, variable contributing area model of basin hydrology, Hydrol. Sci. Bull., 24, 43-69, 1979.

Boone, A., Calvet, J.-C., and Noilhan, J.: Inclusion of a third soil layer in a land surface scheme using the force-restore method, J. Appl. Meteorol., 38, 1611-1630, 1999.

Boone, A., Masson, V., Meyers, T., and Noilhan, J.: The influence of the inclusion of soil freezing on simulation by a soil-atmospheretransfer scheme, J. Appl. Meteorol., 9, 1544-1569, 2000.

Boone, A., Habets, F., Noilhan, J., Clarks, D., Dirmeyer, C., Fox, S., Gusev, Y., Haddeland, I., Koster, R., Lohmann, D., Mahanama, S., Mitchell, K., Nasonova, O., Niu, G.-Y., Pitman, A., Polcher, J., Shmakin, A. B., Tanaka, K., Van Den Hurk, B., Verant, S., Verseghy, D., Viterbo, P., and Yang, Z.-L.: The RhoneAggregation land surface scheme intercomparison project: an overview, J. Climate, 17, 187-208, 2004.

Brut, A., Rüdiger, C., Lafont, S., Roujean, J.-L., Calvet, J.-C., Jarlan, L., Gibelin, A.-L., Albergel, C., Le Moigne, P., Soussana, J.-F., Klumpp, K., Guyon, D., Wigneron, J.-P., and Ceschia, E.: Modelling LAI at a regional scale with ISBA-A-gs: comparison with satellite-derived LAI over southwestern France, Biogeosciences, 6, 1389-1404, doi:10.5194/bg-6-1389-2009, 2009.

Cabezas, A., Comín, F. A., Beguería, S., and Trabucchi, M.: Hydrologic and landscape changes in the Middle Ebro River (NE Spain): implications for restoration and management, Hydrol. Earth Syst. Sci., 13, 273-284, doi:10.5194/hess-13-273-2009, 2009.

Calvet, J.-C.: Investigating soil and atmospheric plant water stress using physiological and micrometeorological data sets, Agr. Forest Meteorol., 103, 229-247, 2000.

Calvet, J.-C. and Soussana, J.-F.: Modelling $\mathrm{CO}_{2}$-enrichment effects using an interactive vegetation SVAT scheme, Agr. Forest Meteorol., 108, 129-152, 2001.

Calvet, J.-C., Noilhan, J., Roujean, J.-L., Bessemoulin, P., Cabelguenne, M., Olioso, A., and Wigneron, J.-P.: An interactive vegetation SVAT model tested against data from six contrasting sites, Agr. Forest Meteorol., 92, 73-95, 1998.

Calvet, J.-C., Rivalland, V., Picon-Cochard, C., and Guehl, J.M.: Modelling forest transpiration and $\mathrm{CO}_{2}$ fluxes - response to soil moisture stress, Agr. Forest Meteorol., 124, 143-156, doi:10.1016/j.agrformet.2004.01.007, 2004. 
Calvet, J.-C., Gibelin, A.-L., Roujean, J.-L., Martin, E., Le Moigne, P., Douville, H., and Noilhan, J.: Past and future scenarios of the effect of carbon dioxide on plant growth and transpiration for three vegetation types of southwestern France, Atmos. Chem. Phys., 8, 397-406, doi:10.5194/acp-8-397-2008, 2008.

Calvet, J.-C., Lafont, S., Cloppet, E., Souverain, F., Badeau, V., and Le Bas, C.: Use of agricultural statistics to verify the interannual variability in land surface models: a case study over France with ISBA-A-gs, Geosci. Model Dev., 5, 37-54, doi:10.5194/gmd-537-2012, 2012.

Christensen, J. H., Hewitson, B., Busuioc, A., Chen, A., Gao, X., Held, I., Jones, R., Kolli, R. K., Kwon, W.-T., Laprise, R., Magaña Rueda, V., Mearns, L., Menéndez, C. G., Räisänen, J., Rinke, A., Sarr, A. and Whetton, P.: Regional Climate Projections, in: Climate Change 2007: The Physical Science Basis. Contribution of Working Group I to the Fourth Assessment Report of the Intergovernmental Panel on Climate Change, edited by: Solomon, S., Qin, D., Manning, M., Chen, Z., Marquis, M., Averyt, K. B., Tignor, M., and Miller, H. L., Cambridge University Press, Cambridge, United Kingdom and New York, NY, USA, 2007.

Ciais, P., Reichstein, M., Viovy, N., Granier, A., Ogée, J., Allard, V., Aubinet, M., Buchmann, N., Bernhofer, C., Carrara, A., Chevallier, F., De Noblet, N., Friend, A. D., Friedlingstein, P., Grünwald, T., Heinesch, B., Keronen, P., Knohl, A., Krinner, G., Loustau, D., Manca, G., Matteucci, G., Miglietta, F., Ourcival, J. M., Papale, D., Pilegaard, K., Rambal, S., Seufert, G., Soussana, J. F., Sanz, M. J., Schulze, E. D., Vesala, T., and Valentini, R.: Europe-wide reduction in primary productivity caused by the heat and drought in 2003, Nature, 437, 529-533, doi:10.1038/nature03972, 2005.

Collatz, G. J., Ribas-Carbo, M., and Berry, J. A.: Coupled photosynthesis-stomatal conductance model for leaves of C4 plants, Aust. J. Plant Physiol., 19, 519-538, 1992.

Deardorff, J. W.: A parametrization of ground-surface moisture content for use in atmospheric prediction model, J. Appl. Meteorol., 16, 1182-1185, 1977.

Deardorff, J. W.: Efficient prediction of ground surface temperature and moisture with inclusion of a layer of vegetation, J. Geophys. Res., 20, 1889-1903, 1978.

Decharme, B.: Influence of the runoff representation on continental hydrology using the NOAH and the ISBA land surface models, J. Geophys. Res., 112, D19108, doi:10.1029/2007JD008463, 2007.

Decharme, B. and Douville, H.: Introduction of a sub-grid hydrology in the ISBA land surface model, Clim. Dynam., 26, 65-78, 2006a.

Decharme, B. and Douville, H.: Uncertainties in the GSWP-2 precipitation forcing and their impacts on regional and global hydrological simulations, Clim. Dynam., 27, 695-713, 2006b.

Decharme, B. and Douville, H.: Global validation of the ISBA SubGrid Hydrology, Clim. Dynam., 29, 21-37, doi:10.1007/s00382006-0207-8, 2007.

Decharme, B., Douville, H., Boone, A., Habets, F., and Noilhan, J.: Impact of an exponential profile of saturated hydraulic conductivity within the ISBA LSM: simulations over the Rhone basin, J. Hydrometeorol., 7, 61-80, 2006.

Decharme, B., Alkama, R., Douville, H., Becker, M., and Cazenave, A.: Global evaluation of the ISBA-TRIP continental hydrologic system, Part 2: Uncertainties in river routing simulation related to flow velocity and groundwater storage, J. Hydrometeorol., 11, 601-617, 2010.

Decharme, B., Boone, A., Delire, C., and Noilhan, J.: Local evaluation of the interaction between soil biosphere atmosphere soil multilayer diffusion scheme using four pedotransfer functions, J. Geophys. Res., 116, D20126, doi:10.1029/2011JD016002, 2011.

Decharme, B., Alkama, R., Papa, F., Faroux, S., Douville, H., and Prigent, C.: Global off-line evaluation of the ISBA-TRIP flood model, Clim. Dynam., 38, 1389-1412, doi:10.1007/s00382-0111054-9, 2012.

Dee, D. P., Uppala, S. M., Simmons, A. J., Berrisford, P., Poli, P., Kobayashi, S., Andrae, U., Balmaseda, M. A., Balsamo, G., Bauer, P., Bechtold, P., Beljaars, A. C. M., van de Berg, L., Bidlot, J., Bormann, N., Delsol, C., Dragani, R., Fuentes, M., Geer, A. J., Haimberger, L., Healy, S., Hersbach, H., Holm, E. V., Isaksen, L., Kallberg, P., Kohler, M., Matricardi, M., McNally, A. P., Monge-Sanz, B. M., Morcrette, J.-J., Peubey, J., de Rosnay, P., Tavolato, C., Thepaut, J.-N., and Vitart, F.: The ERA-Interim reanalysis: Conguration and performance of the data assimilation system, Q. J. Roy. Meteorol. Soc., 137, 553597, doi:10.1002/qj.828, 2011.

Dirmeyer, P. A., Gao, X., Zhao, M., Guo, Z., Oki, T., and Hanasaki, N.: GSWP-2: Multimodel analysis and implications for our perception of the land surface, B. Am. Meteorol. Soc., 87, 13811397, doi:10.1175/BAMS-87-10-1381, 2006.

Douville, H., Royer, J.-F., and Mahfouf, J.-F.: A new snow parameterization for the Météo-France climate model, Part I: validation in stand-alone experiments, Clim. Dynam., 12, 21-35, 1995.

Dümenil, L. and Todini, E.: A rainfall-runoff scheme for use in the Hamburg climate model, Adv. Theor. Hydrol., 9, 129-157, 1992.

Farquhar, G. D., von Caemmerer, S., and Berry, J. A.: A biochemical model of photosynthetic $\mathrm{CO}_{2}$ assimilation in leaves of $\mathrm{C} 3$ species, Planta, 149, 78-90, 1980.

Faroux, S., Roujean, J.-L., Kaptue, A., and Masson, V.: La base de données ECOCLIMAP-II sur l'Europe, Note du Groupe de Météorologie à moyenne échelle, 86, 120 pp., 2009.

Fekete, B. M., Vorósmarty, C. J., Road, J. O., and Willmott, C. J.: Uncertainties in precipitation and their impacts on runoff estimates, J. Climate, 17, 294-304, 2003.

Fuchs, T., Schneider, U., and Rudolf, B.: The Global Precipitation Climatology Centre (GPCC) - in situ observation based precipitation climatology on regional and global scale, Geophys. Res. Abstr., EGU2009-10519, EGU General Assembly 2009, Vienna, Austria, 2009.

García-Herrera, R., Hernandez, E., Barriopedro, D., Paredes, D., Trigo, R. M., Franco Trigo, I., and Mendes, M. A.: The outstanding 2004/05 drought in the Iberian peninsula: associated atmospheric circulation, J. Hydrometeorol., 8, 483-498, doi:10.1175/JHM578.1, 2007.

Gibelin, A. L. and Déqué, M.: Anthropogenic climate change over the Mediterranean region simulated by a global variable resolution model, Clim. Dynam., 20, 327-339, 2003.

Gibelin, A.-L., Calvet, J.-C., Roujean, J.-L., Jarlan, L., and Los, S.: Ability of the land surface model ISBA-A-gs to simulate leaf area index at the global scale: comparison with satellites products, J. Geophys. Res., 111, D18102, doi:10.1029/2005JD006691, 2006.

Gibelin, A.-L., Calvet, J.-C., and Viovy, N.: Modelling energy and $\mathrm{CO}_{2}$ fluxes with an interactive vegetation land surface model evaluation at high and middle latitudes, Agr. Forest Meteorol., 
148, 1611-1628, 2008.

Giorgi, F.: Climate change hot-spots, Geophys. Res. Lett., 33, L08707, doi:10.1029/2006GL025734, 2006.

Global Runoff Data Centre, Federal Institute of Hydrology (BfG), Am Mainzer Tor 1, 56068 Koblenz, Germany, available at: http: //www.bafg.de/GRDC/EN/Home/homepage__node.html, last access: July 2012.

Goudriaan, J., van Laar, H. H., van Keulen, H., and Louwerse, W.: Photosynthesis, $\mathrm{CO}_{2}$ and plant production, in: Wheat Growth and Modelling, edited by: Day, W. and Atkin, R. K., NATO ASI Series, Plenum Press, New York, Series A, 86, 107-122, 1985.

Grippa, M., Mognard, N., and Le Toan, T.: Comparison between the interannual variability of snow parameters derived from SSM/I and the $\mathrm{Ob}$ river discharge, Remote Sens. Environ., 98, 35-44, 2005.

Habets, F., Etchevers, P., Golaz, C., Leblois, E., Ledoux, E., Martin, E., Noilhan, J., and Ottle, C.: Simulation of the water budget and the river flows of the Rhone basin, J. Geophys. Res., 104, 3114531172, 1999.

Hanasaki, N., Kanae, S., and Oki, T.: A reservoir operation scheme for global river routing models, J. Hydrol., 327, 22-41, 2006.

Huffman, G. J., Adler, R. F., Bolvin, D. T., and Gu, G.: Improving the global precipitation record: GPCP Version 2.1, Geophys. Res. Lett., 36, L17808, doi:10.1029/2009GL040000, 2009.

HyMeX White Book: 123 pp., available at: http://www.hymex.org (last access: July 2012), 2008.

Immerzeel, W. W., Droogers, P., de Jong, S. M., and Bierkens, M. F. P.: Large-scale monitoring of snow cover and runoff simulation in Himalayan river basins using remote sensing, Remote Sens. Environ., 113, 40-49, 2009.

Jacobs, C. M. J.: Direct impact of $\mathrm{CO}_{2}$ enrichment on regional transpiration, Ph.D, Thesis, Agricultural University, Wageningen, 1994.

Jacobs, C. M. J., Van den Hurk, B. J. J. M., and De Bruin, H. A. R.: Stomatal behaviour and photosynthetic rate of unstressed grapevines in semi-arid conditions, Agr. Forest Meteorol., 80, 111-134, 1996.

Jarvis, P. G.: The interpretation of leaf water potential and stomatal conductance found in canopies in the field, Philos. T. Roy. Soc. B, 273, 593-610, 1976.

Krause, P., Boyle, D. P., and Base, F.: Comparison of different efficiency criteria for hydrological model assessment, Adv. Geosci., 5, 89-97, doi:10.5194/adgeo-5-89-2005, 2005.

Lafaysse, M., Hingray, B., Etchevers, P., Martin, E., and Obled, C.: Influence of spatial discretization, underground water storage and glacier melt on a physically-based hydrological model of the Upper Durance River basin, J. Hydrol., 403, 116-129, 2011.

Lafont, S., Zhao, Y., Calvet, J.-C., Peylin, P., Ciais, P., Maignan, F., and Weiss, M.: Modelling LAI, surface water and carbon fluxes at high-resolution over France: comparison of ISBA-A-gs and ORCHIDEE, Biogeosciences, 9, 439-456, doi:10.5194/bg9-439-2012, 2012.

Le Moigne, P.: SURFEX scientific documentation, Note de centre du Groupe de Metéorologie à Moyenne Echelle, Météo-France, CNRM, Toulouse, 87, 211 pp., available at: http://www.cnrm. meteo.fr/surfex/ (last access: July 2010), 2009.

Lohmann, D., Lettenmaier, D. P., Liang, X., Wood, E. F., Boone, A., Chang, S., Chen, F., Dai, Y., Desborough, C., Dickinson, R. E., Duan, Q., Ek, M., Gusev, Y. M., Habets, F., Irannejad,
P., Koster, R., Mitchell, K. E., Nasonova, O. N., Noilhan, J., Schaake, J., Schlosser, A., Shao, Y., Shmakin, A. B., Verseghy, D., Warrach, K., Wetzel, P., Xue, Y., Yang, Z.-L, and Zeng, Q.C.: The Project for Intercomparison of Land-Surface Parameterization Schemes (PILPS) Phase-2c Red-Arkansas River Basin experiment: III. Spatial and temporal analysis of water fluxes, Global Planet. Change, 19, 161-180, 1998.

Ludwig, W., Dumont, E., Meybeck, M., and Heussner, S.: River discharges of water and nutrients to the Mediterranean and Black Sea: Major drivers for ecosystem changes during past and future decades?, Prog. Oceanogr., 80, 199-217, doi:10.1016/j.pocean.2009.02.001, 2009.

Mariotti, A., Struglia, M. V., Zeng, N., and Lau, K.-M.: The hydrological cycle in the Mediterranean region and implications for the water budget of the Mediterranean Sea, J. Climate, 15, 1674 1690, 2002.

Masson, V., Champeaux, J.-L., Chauvin, F., Meriguet, C., and Lacaze, R.: A global database of land surface parameters at $1 \mathrm{~km}$ resolution for use in meteorological and climate models, J. Climate, 16, 1261-1282, 2003.

Miguez-Macho, G., Fan, Y., Weaver, C.-P., Walko, R., and Robock, A.: Incorporating water table dynamics in climate modeling: 2. Formulation, validation, and soil moisture simulation, J. Geophys. Res., 112, D13108, doi:10.1029/2006JD008112, 2007.

Nash, J. E. and Sutcliffe, J. V.: River flow forecasting through conceptual models: 1. A discussion of principles, J. Hydrol., 10, 282-290, 1970.

Niu, G. Y. and Yang, Z.-L.: Effects of frozen soil on snowmelt runoff and soil water storage at a continental scale, J. Hydrometeorol., 7, 937-952, 2006.

Noilhan, J. and Mahfouf, J.-F.: The ISBA land surface parameterization scheme, Global Planet. Change, 13, 145-149, 1996.

Noilhan, J. and Planton, S.: A simple parameterisation of Land Surface Processes for meteorological model, Mon. Weather Rev., 117, 356-549, 1989.

Noilhan, J., Donier, S., Lacarrere, P., Sarrat, C., and Le Moigne, P.: Regional-scale evaluation of a land surface scheme from atmospheric boundary layer observations, J. Geophys. Res.-Atmos., 116, D01104, doi:10.1029/2010JD014671, 2011.

Oki, T. and Sud, Y. C.: Design of Total Runoff Integrating Pathways (TRIP) - a global river channel network, Earth Interact., 2, 1-37, 1998.

Oki, T., Nishimura, T., and Dirmeyer, P.: Validating estimates of land surface parameterizations by annual discharge using total runoff integrating pathways, J. Jpn. Soc. Hydrol. Water Resour., 9, 416-425, 1997.

Oki, T., Nishimura, T., and Dirmeyer, P.: Assessment of annual runoff from land surface models using Total Runoff Integrating Pathways (TRIP), J. Meteorol. Soc. Jpn., 77, 235-255, 1999.

Papa, F., Prigent, C., Aires, F., Jimenez, C., Rossow, W. B., and Matthews, E.: Interannual variability of surface water extent at the global scale, 1993-2004, J. Geophys. Res., 115, D12111, doi:10.1029/2009JD012674, 2010.

Photiadou, C. S., Weerts, A. H., and van den Hurk, B. J. J. M.: Evaluation of two precipitation data sets for the Rhine River using streamflow simulations, Hydrol. Earth Syst. Sci., 15, 3355-3366, doi:10.5194/hess-15-3355-2011, 2011.

Planton, S., Lionello, P., Artale, V., Aznar, R., Carillo, A., Colin, J., Congedi, L., Dubois, C., Elizalde Arellano, A., Gualdi, S., Her- 
tig, E., Jorda Sanchez, G., Li, L., Jucundus, J., Piani, C., Ruti, P., Sanchez-Gomez, E., Sannino, G., Sevault, F., and Somot, S.: The climate of the Mediterranean region in future climate projections, in: The Climate of the Mediterranean Region, Chapt. 8, 1st Edn., edited by: Lionello, P., Elsevier, 2012.

Queguiner, S., Martin, E., Lafont, S., Calvet, J.-C., Faroux, S., and Quintana-Seguí, P.: Impact of the use of a $\mathrm{CO}_{2}$ responsive land surface model in simulating the effect of climate change on the hydrology of French Mediterranean basins, Nat. Hazards Earth Syst. Sci., 11, 2803-2816, doi:10.5194/nhess-11-28032011, 2011.

Quintana-Segui, P., Lemoigne, P., Durand, Y., Martin, E., Habets, F., Baillon, M., Canellas, C., Franchisteguy, L., and Morel, S.: Analysis of near surface atmospheric variables: Validation of the SAFRAN analysis over France, J. Appl. Meteorol. Clim., 47, 92107, 2008.

Rudolf, B., Beck, C., Grieser, J., and Schneider, U.: Global Precipitation Analysis Products, Global Precipitation Climatology Centre (GPCC), DWD, Internet publication, 1-8, 2005.

Rudolf, B., Becker, A., Schneider, U., Meyer-Christoffer, A., and Ziese, M.: The new "GPCC Full Data Reanalysis Version 5" providing high-quality gridded monthly precipitation data for the global land-surface is public available since December 2010, 7 pp., DWD, Internet Publication, available at: http://www.dwd.de/bvbw/generator/DWDWWW/ Content/Oeffentlichkeit/KU/KU4/KU42/Publikationen/ GPCC__status__report__2010,templateId=raw, property= publicationFile.pdf/GPCC_status_report_2010.pdf (last access: July 2012), 2010.

Sanchez-Gomez, E., Somot, S., Josey, S. A., Dubois, C., Elguindi, N., and Déqué, M.: Evaluation of the Mediterranean Sea Water and Heat budgets as simulated by an ensemble of high resolution Regional Climate Models, Clim. Dynam., 37, 2067-2086, doi:10.1007/s00382-011-1012-6, 2011.
Simmons, A., Uppala, S., Dee, D., and Kobayashi, S.: ERA-I: New ECMWF reanalysis products from 1989 onwards, ECMWF Newsl., 110, 25-35, 2007.

Struglia, M. V., Mariotti, A., and Filograsso, A.: River discharge into the Mediterranean Sea: Climatology and aspects of the observed variability, J. Climate, 17, 4740-4751, 2004.

Syed, T. H., Lakshmi, V., Paleologos, E., Lohmann, D., Mitchell, K., and Famiglietti, J. S.: Analysis of process controls in land surface hydrological cycle over the continental United States, J. Geophys. Res., 109, D22105, doi:10.1029/2004JD004640, 2004.

Szczypta, C., Calvet, J.-C., Albergel, C., Balsamo, G., Boussetta, S., Carrer, D., Lafont, S., and Meurey, C.: Verification of the new ECMWF ERA-Interim reanalysis over France, Hydrol. Earth Syst. Sci., 15, 647-666, doi:10.5194/hess-15-647-2011, 2011.

Tate, E. L. and Gustard, A.: Drought definition: a hydrological perspective, in: Drought and Drought Mitigation in Europe, edited by: Vogt, J. J. and Somma, F., Kluwer Acad. Publ., Dordrecht, 23-48, 2000.

van Dijk, A. I. J. M. and Renzullo, L. J.: Water resource monitoring systems and the role of satellite observations, Hydrol. Earth Syst. Sci., 15, 39-55, doi:10.5194/hess-15-39-2011, 2011.

Vergnes, J.-P., Decharme, B., Alkama, R., Martin, E., Habets, F., and Douville, H.: A Simple Groundwater Scheme for Hydrological and Climate Applications: Description and Offline Evaluation over France, J. Hydrometeorol., 13, 1149-1171, doi:10.1175/JHM-D-11-0149.1, 2012.

Vidal, J.-P., Martin, E., Franchistéguy, L., Habets, F., Soubeyroux, J.-M., Blanchard, M., and Baillon, M.: Multilevel and multiscale drought reanalysis over France with the Safran-Isba-Modcou hydrometeorological suite, Hydrol. Earth Syst. Sci., 14, 459-478, doi:10.5194/hess-14-459-2010, 2010.

Wilhite, D. A. and Glantz, M. H.: Understanding the drought phenomenon: the role of definitions, Water Int., 10, 111-120, 1985. 